\title{
THE LEGITIMACY OF THE COLLECTIVE AUTHORITY OF THE SECURITY COUNCIL
}

\author{
By David D. Caron*
}

The ideal, once it is embodied in an institution; ceases to be an ideal and becomes the expression of a selfish interest, which must be destroyed in the name of a new ideal. This constant interaction of irreconcilable forcess is the stuff of politics. Every political situation contains mutually incompatible elements of utopia and reality, of morality and power.

E. H. Carr

[T] he crucial question is not what principle is acknowledged but who is accepted as the authoritative interpreter of the principle or, to put it in institutional terms, how the process of legitimization works.

Inis Claude, $J r^{2}$

\section{INTRODUCTION}

At this pivotal point in history, a fundamental and oft-raised issue is "international governance." Means of effective governance are seen as necessary to more complex arrangements of world order. But achieving effective governance ultimately will mean the existence of institutions that legislate, that is, institutions that make decisions binding on the whole. As a general matter, states have been skeptical of, if not hostile toward and consequently unwilling to accept, such governance. The United Nations Security Council is a notable exception; in the sometimes broad, sometimes narrow, area of international peace and security, the Security Council has taken decisions in the name of, and binding upon, the entire international community. ${ }^{3}$

* Of the Board of Editors. Earlier drafts of this article were presented at the Institute of International Studies, the University of California at Berkeley, on November 9, 1992; at a joint United Nations Association/Russian Foreign Policy Association/American Society of International Law Conference in Moscow on December 7, 1992; before the U.S. Commission on Improving the Effectiveness of the United Nations on February 2, 1993; at the Annual Meeting of The American Society of International Law in Washington, D.C., on April 2, 1993; and at a meeting of government and UN lawyers who work with the Sixth Committee of the General Assembly in New York on May 6, 1993. The article benefited greatly from the discussions at these meetings and from the conments of many colleagues and officials.

${ }^{1}$ EDWard Hallett Carr, The Twenty Years' Crisis: 1919-1939, at 94 (2d ed. 1945).

2 Inis Claude, Jr., Collective Legitimization as a Political Function of the United Nations, 20 INT'L ORG. 367, 369-70 (1966).

${ }^{3}$ Article $39(1)$ of the Charter provides that the trigger for action under Articles 41 and 42 shall be the determination by the Council of "the existence of any threat to the peace, breach of the peace or act of aggression." On the meaning of "threat to the peace," see LELAND GoODRICH, EDVARD HAMbro \& Anne Patricia Simons, Charter of the United Nations: Commentary and Documents 295-97 (3d rev. ed. 1969).

For examples of a recent trend to interpret "threat to the peace" more broadly than previously, see SC Res. 688 (Apr. 5, 1991), reprinted in 30 ILM 858 (1991) (determining that Iraqi actions in the Kurdish areas of Iraq were a threat to regional peace and security); and SC Res. 794 (Dec. 3, 1992) (determining that the "magnitude of the human tragedy caused by the conflict in Somalia" constituted a threat to international peace and security). 
With the end of the Cold War, the most apparent ideological distinctions between East and West, political and economic, ended. As the "First" and "Second" worlds merged, the Iraqi invasion of Kuwait swept the world up in an endeavor that breathed new life into a United Nations long hobbled by the East-West conflict. The Security Council acted in utterly unprecedented ways: ordering economic sanctions and, ultimately, authorizing the use of force by "Member States co-operating with the Government of Kuwait" so as to implement the resolutions of the Council and "restore international peace and security in the area." This vitality has continued in the United Nations with the imposition of economic sanctions against Libya, ${ }^{5}$ Serbia $^{6}$ and, most recently, Haiti. ${ }^{7}$

It is thus with no small measure of irony that, as the international community finally achieved what quite a few of its members at least officially had sought-a functioning UN Security Council-many of them began to have second thoughts about the legitimacy of that body's use of its collective authority. For some, this irony has yielded to cynicism regarding the Council. However, in view of the central role of the Security Council, both now and in the future, this irony must also give rise to determination to renew the Council and lay the basis for models of governance generally. This article explores the roots and relevance of chal-

A particularly interesting recent issue involves the competence of the Security Council to establish, by binding decision, an ad hoc criminal court. See Letter from the Permanent Representative of France to the Secretary-General, UN Doc. S/25266 (1993). "[T]he establishment of a [ad hoc] Tribunal would be an appropriate measure if . . . it seems likely to attain or facilitate the objective of restoring international peace and security." Id. at 13. The Council ultimately established an ad hoc tribunal in Resolution 827 (May 25, 1993).

SC Res. 678, para. 2 (Nov. 29, 1990), reprinted in 29 ILM 1565 (1990).

${ }^{5}$ In response to the destruction of Pan Am Flight 103 and UTA Flight 772, the Security Council unanimously passed Resolution 731, inter alia, urging the Libyan Government to comply with requests for the surrender of the bombing suspects for trial in the United States or the United Kingdom, the disclosure of all relevant information and the payment of appropriate compensation. SC Res. 731 (Jan. 21, 1992), reprinted in 31 ILM 732 (1992). When Libya failed to comply, the Security Council, acting under chapter VII, passed by a vote of 10 for, 0 against and 5 abstentions (Cape Verde, China, India, Morocco, Zimbabwe), Resolution 748 imposing diplomatic and economic sanctions upon Libya if Libya failed to comply with the demands in Resolution 731 and to take concrete steps toward ceasing all terrorist actions by April 15, 1992. SC Res. 748 (Mar. 31, 1992), reprinted in 31 ILM at 750 .

"In response to the violence in Bosnia and Hercegovina, the Security Council adopted Resolution 752 (May 15, 1992), reprinted in 31 ILM at 1451, setting forth various demands aimed at ending the fighting. On May 30, 1992, the Security Council, acting under chapter VII, passed by 13 votes for, 0 against and 2 abstentions (China, Zimbabwe), Resolution 757, reprinted in 31 ILM at 1453, imposing economic and diplomatic sanctions against the Federal Republic of Yugoslavia (Serbia and Montenegro) until such time as the Council found that Serbia and Montenegro had complied with Resolution 752. These sanctions were expanded upon in several Security Council resolutions over the next year.

${ }^{7}$ For recent UN actions, see Howard French, U.N. Approves Ban on Shipments of Oil to Haitian Miltary, N.Y. TIMES, June 17, 1993, at A1; and Paul Lewis, U.N. Council Plans to Order Full Ban on Oil for Haiti, N.Y. TIMES, June 10, 1993, at A1.

Earlier, the Organization of American States had authorized more limited sanctions against Haiti. On September 30, 1991, the OAS Permanent Council, established only recently under Resolution AG/RES.1080 (XXI-0/91) and acting pursuant to its authority under Article 64 of the OAS Charter, as amended by the Protocol of Cartagena de Indias in 1985 (Doc. OEA/Ser.A/41), convened an ad hoc Meeting of Consultation of Ministers of Foreign Affairs. That body, without veto, adopted by consensus Resolutions MRE/RES.1/91 and MRE/RES.2/91 on October 3 and 8, 1991, respectively. Those resolutions are nonbinding appeals by the regional body for its 34 members and other governments to halt all commercial and financial transactions with Haiti until President Jean-Bertrand Aristide is restored to office. 
lenges to the legitimacy of the Council's use of its authority, and suggests some ways that the forces motivating such challenges may be addressed. ${ }^{8}$

A basic assumption often made in discussions regarding allegations of illegitimacy is that those allegations make a practical difference. Whether this assumption is warranted is touched upon in part I. Accepting this assumption for the moment, however, the conclusion reached in the case of the Security Council is that the likelihood of continued collective action depends in part on the perceived legitimacy of the decision maker, the Council itself. But, as Andrew Boyd observed of the Council twenty years ago, "the first time the tool is used there are almost bound to be complaints, from one quarter or another, that it is bent sinisterly." Even amid the virtually universal agreement that the Iraqi invasion should be reversed, some were uneasy about specific aspects of the Security Council's decision. ${ }^{10}$ Like concerns have been voiced in the months since, both generally, ${ }^{11}$ and particularly when the Council acted in regard to Libya. ${ }^{12}$

${ }^{8}$ I gain the impression from individuals involved with the Security Council that the cutting edge or their concerns about the Council is shifting. Two years ago, even one year ago, the concern of a substantial group of states was, as noted in the text, the legitimacy of the Council's use of its authority. Against the background of the difficult situations in Serbia, Somalia and Cambodia and the hard task of finding resources to match both rhetoric and aspiration, the concern of many now is with the reality of the Council's "power." See, e.g., Paul Lewis, U.N. is in Arrears on Peace Efforts: Increased Costs Raise Doubts About Ability to Finance Its Future Operations, N.Y. TimEs, May 16, 1993, §1, at 9; Richard Bernstein, Sniping is Growing at U.N.'s Weakness as a Peacekeeper, N.Y. 'TIMES, June 21, 1993, at A1; The United Nations: Heart of gold, limbs of clay, EcoNOMIST, June 12, 1993, at 21. If the United States does not assume the burden of making real the orders of the Council, as in the case of Iraq's invasion of Kuwait, is the Council revealed as a paper tiger mostly roaring condemnations and occasionally establishing regimes of economic sanctions of questionable efficacy? "There isn't any concert of powers out there to join. If there is to be collective action, it will happen only if the U.S. not only participates, but plays a leading constructive role." Jeane Kirkpatrick, Facing a World Without Threats, NEw Perspectives Q., Summer 1992, at 10, 12. See also Michael Gordon, New Strength for U.N. Peacekeepers: U.S. Might, N.Y. TMmes, June 13, 1993, \$1, at 11 . Although senous indeed, this more recent concern about power does not moot the earlier concern about legitinacy. The more recent concern may increasingly preoccupy those on the front line, but ultimately we will need to address the first.

${ }^{9}$ ANDrew Boxd, Fifteen Men ON A POWDER Keg: A History of the U.N. Securtry Council 222 (1971).

${ }^{10}$ For example, the Colombian representative stated just prior to the adoption of Resolution 665 , the resolution authorizing the use of maritime forces to implement provisions of the economic sanctions against Iraq:

We are under no illusion that when the Council comes to vote on this draft resolution it will be establishing a naval blockade. . . .

That neither worries nor frightens us, but we wish to be candid: We feel concern . . . over the fact that in this draft resolution the Security Council is delegating authority without specifying to whom. Nor do we know where that authority is to be exercised or who receives it. Indeed, whoever does receive it is not accountable to anyone.

UN Doc. S/PV.2938, at 21 (1990).

Many more, and much stronger, statements can be found by persons who do not represent a government. See, e.g., Erskine Childers, Gulf Crisis Lessons for the UN, 23 Bull. PEACE Proposals 129 (1992).

${ }^{11}$ See, e.g., the statements of various states during the UN debate on the Agenda for Peace, infra note 16, summarized in Peter J. Fromuth, The Making of a Security Community: The United Nations After the Cold War, 46 J. INr'L AFr. 341, 363 (1993). See also Charley Reese, The U.N.: Just a Front, OARLAND TRIB., Dec. 15, 1992, at A13.

${ }^{12}$ See, e.g., Badi M. Ali,"White House Plays the Libya Card, N.Y. Trmes, May 5, 1992, at A18 (letter to the editor). The Economist expressed the general sense of these concerns, observing: "The council, 
Thus, as the ideological obstacles to collective action that characterized the Cold War appear to have receded (or at least greatly diminished, since China-or any permanent member for that matter-with its veto could end the activism of the Security Council), the international community faces the perennial core questions of how to decide that a threat to international peace and security.exists and that collective action is required. There are at least two aspects to these questions: the first concerns the acceptability to various states of the process of decision in the Security Council; and the second inquires into principled justifications for collective action. Although I focus here on the process of decision, consideration of both aspects is essential to the rejuvenation of the Council. Consequently, this article should be viewed in combination with the work of other groups exploring the substantive bases of collective action. ${ }^{13}$

These fundamental questions regarding the Council reassert themselves at a time when change seems both possible and overdue. It is a time when many question whether the correct states hold the veto. ${ }^{14}$ It is a time when the Soviet Union dissolved and succession to its seat and veto became an issue. ${ }^{15}$ Finally, it is a time when fundamental change in the United Nations seems possible as a result of both the renewal of interest in the Organization since the gulf war and the upcoming fiftieth anniversary of the Charter. ${ }^{16}$

In examining the Security Council's exercise of collective authority, I found my research and conversations with colleagues continually returning to basic questions as to what it means to speak of an institution's use of authority as illegitimate. Part I briefly considers these basic questions. ${ }^{17}$ Part II identifies and discusses five particular circumstances that underpin two broad perceptions of illegitimacy regarding the collective authority of the Security Council. ${ }^{18}$ In part III I evaluate whether proposals for reform of the Council are addressed to these five circumstances. The proposals include reforming the veto, increasing the Council's membership and opening up its proceedings so as to engender a sense of greater participation in the Council by UN members generally. The first route, reforming the veto, does not appear likely to occur any time in the near future. The second, increasing the size of the Council, indirectly might increase the perception of

exult northerners, has been reborn to keep the peace in a manner that fits with modern times. No, grumble southerners, the council is becoming a flag of convenience for old-time neo-imperialists." Open the Club, ECONOMIST, Aug. 29, 1992, at 14.

${ }^{13}$ Such an inquiry is currently under way in several forums, including the American Academy of Arts and Sciences, the Council on Foreign Relations and the Henry L. Stimson Center. See, e.g., EMERGING NORMS OF JUSTIFIEd INTERvention (Laura W. Reed \& Carl Kaysen eds., 1993); W. J. Durch \& B. M. Blechman, Keeping the Peace: The United Nations in the Emerging World ORDER (1992); and LAW AND Force IN THE NEW INTERNATIONAL ORDER (Lori F. Damrosch \& David J. Scheffer eds., 1991). See also Peter Malanczuk, Humanitarian Intervention and the LegrtiMACX OF THE USE OF FORCE (1993).

it Srk, e.g., Open the Club, supra note 12, at 14 ("The council is an anachronism.").

15 Sra', e.g., Yehuda Z. Blum, Russia Takes Over the Soviet Union's Seat at the United Nations, 3 EUR. J. INT'L. L. 354 (1992); Richard Gardner \& Toby Trister Gati, Russia Deserves the Soviet Seat, N.Y. TImEs, Dec. 19, 1991, at A31; and Stefan A. Riesenfeld \& Frederick Abbott, A UN Dilemma: Who Gets the Soviet Seat on the Security Council?, Christran Sci. Monitor, Oct. 4, 1991, at 19.

${ }^{15}$ See, e.g., An Agenda for Peace, Preventive diplomacy, peacemaking and peace-keeping-Report of the Secretary-General, UN Doc. A/47/277-S/24111, para. 85 (1992), reprinted in 31 ILM 953 (1992) ("the present phase in the renewal of this Organization should be complete by 1995 . . .").

${ }^{17}$ For a related discussion, see David D. Caron, Governance and Collective Legitimation in the New World Order, HAGUE Y.B. INT'L L. (forthcoming).

${ }^{1 \times}$ For a summary listing of these circumstances, see p. 566 infra. 
legitimacy, but risks weakening the Council's ability to function. The third, opening up the proceedings, holds the most promise of minimizing perceptions of illegitimacy, but likely will not suffice.

Since the veto will probably last for some time, part IV suggests practical means to deal in part with the legitimacy concerns expressed. Specifically, I identify and explore a new use of the veto-which I term the "reverse veto"-that tends to undercut the legitimacy of the Security Council's collective authority. In particular, I point to the importance of distinguishing between the authority to initiate an action and the authority to modify an action already initiated. Recommendations are put forward for dealing with this use of the veto that, unlike proposals generally involving the veto, do not require amendment of the Charter.

The structure of the Security Council was and will be a political decision mixing "elements of utopia and reality, of morality and power." But the wisdom of the initial political decision may diminish over time and structural changes are not easily gained in international organization. Yet, although aspects of the Council are indeed anachronistic, it is functioning and, overall, functioning well in difficult circumstances. The challenge is to refashion the ideal without losing the reality.

\section{I. "LEGITIMACY" IN THE CONTEXT OF INTERNATIONAL GOVERNANCE}

If this study in part seeks to understand and respond to questions regarding the legitimacy of the Council's use of its authority, then it is essential that we understand what motivates and influences such questions. In recent years there has been substantial discussion of the notion of "legitimacy" by the legal community in general, and the academic international legal community in particular. ${ }^{19}$ The extent of this discussion, however, is quite small in comparison to the degree to which this rather nebulous term is loosely employed. It is not the purpose of this

\footnotetext{
${ }^{19}$ A central part of the recent international law discussion is THOMAS M. FRANCK, THE POWER OF Legrtimacy Among NAtions (1990). As to associated commentary, see, e.g., Jose E. Alvarez, The Quest for Legitimacy: An Examination of "The Power of Legitimacy Among Nations" by Thomas $M$. Franck, 24 N.Y.U. J. INT'L L. \& PoL. 199 (1991); Dencho Georgiev, Letter to the Editor, 83 AJIL 554 (1989); and Martti Koskenniemi, Book Review, 86 AJIL 175 (1992).

See generally ERnSt B. HAas, When KNOwledge Is Power: Three Models of Change in INTERNAmonal Organizations (1990); TOM Tyler, Why PeOple Obey the LAw (1990); Margherita Ciacci, Legitimacy and the Problems of Governance, in LegrTIMACY/LÉGrTImTÉ 20 (Athanasios Moulakis ed., 1986); Claude, supra note 2; Maurice Cranston, From Legitimism to Legitimacy, in LEGITIMACY/ LÉGITIMITÉ, supra, at 36; JÜRGEN HABERMAS, Legitimationsprobleme in modernen Stial, in ZUR REKONSTRUKTION DES HISTORISCHEN MATERIALISMUS (1976), translated in JüRGEN HABERMAS, CoMMUNICATION AND THE EVOLUTION OF SOCIETY 178 (T. McCarthy trans., 1979) [hereinafter Legitimation]; Alan Hyde, The Concept of Legitimation in the Sociology of Law, 1983 WIs. L. REv. 379; Tilo Schabert, Power, Legitimacy and Truth: Reflections on the Impossibility to Legitimise Legitimations of Political Order, in LeGrTMACX/LÉGITIMrÉ, supra, at 96; Jerome Slater, The Limits of Legitimization in International Organizations: The Organization of American States and the Dominican Crisis, 23 INT'L ORG. 48 (1969); Joseph H. Weiler, Parlement européen, intégration européenne, démocratie et légitimité, in LE PARLEMENT EUROPÉEN 325 (1988), in English in part in The Transformation of Europe, 100 YALE L.J. 2403, 2466-74 (1991) [hereinafter Transformation]. The relationship between ethics and power, a central part of the discussion of legitimacy, is examined in literature not specifically concerned with legitimacy. See, e.g., Hedley Bull, The ANarchical Society: A STUdy Of ORder IN World PoliTICS (1977); and CARR, supra note 1. Despite the rather curious statement by Koskenniemi, supra, at 175, that "legitimacy" is "a recent innovation. . . . Hobbes . . . had no use for it," the basic questions implicit in the notion of "Iegitimacy" have deep roots in the literature. See, e.g., Cranston, supra (discussing conceptions of legitimacy "well before the French Revolution").
} 
article to set forth a general account of the notion of legitimacy in international governance; rather, in this section I present some basic observations so as to situate the inquiry and analysis that follow.

Legitimacy is approached here primarily in social and political terms; I focus specifically on the political and social dynamic that accompanies allegations of illegitimacy. ${ }^{20}$ As an occasional feature of political discourse, perceptions that a process is "illegitimate" are difficult to describe because they reflect subjective conclusions, perhaps based on unarticulated notions about what is fair and just, or perhaps on a conscious utilitarian assessment of what the process means for oneself. $^{21}$ At a minimum, allegations of illegitimacy manifest dissatisfaction with an organization. ${ }^{22}$

If this study also suggests that attention be given to perceptions of illegitimacy, then it is important that we understand whether and when such perceptions in a practical sense warrant attention. Although I think it clear that perceptions of illegitimacy can matter, precisely when and how they matter is hard to say because the determinants of their significance in practice remain unclear. ${ }^{23}$ Is an organization perceived as legitimate more likely to be used and thus more likely to operate

2"This perspective parallels Habermas's view in Legitimation, supra note 19, at 178, that "[1]egitimacy means a political order's worthiness to be recognized." It is, however, both very difficult and simplistic to characterize one's task as simply to observe the phenomenon of legitimacy. In part, emphasis on understanding the social and political dynamic of legitimacy, rather than the philosophical inquiry into what forms of governance are "just," reflects the lack of consensus on the latter and the potentially persuasive allegations implicit in the former.

An ronic consequence of this normative ambiguity is that the process by which concerns about illegitimacy are addressed may become the best substitute for consensus about what is legitimate. This observation also explains why my attempt here to provide an account of a dynamic shades into process serving as a strategy for reconciliation, which perhaps could lead to consensus at least as to what is illegitimate. See, e.g., HAAs, supra note 19, at 193 ("Moral progress, if it is to be attained by means associated with international organizations, must be defined in procedural terms.").

"In an approach focusing on the social phenomenon of legitimacy, "[t]he legitimacy of an order of domination is measured against the belief in its legitimacy on the part of those subject to the domination." Habermas, Legitimation, supra note 19 , at 199 . For HAAs, supra note 19 , at 87 , legitimacy similarly, but perhaps with more calculation by those accepting it, "exists when the membership values the organization and generally implements collective decisions because they are seen to serve the nembers' values."

22 In this sense, statements voicing mistrust or suspicion of the motives of the permanent members of the Council represent related manifestations of negative assessments of the Council.

"2x Both Franck's and Haas's comments on legitimacy, as indeed my own, are based on a theoretical, nomenpirical inquiry. None of us, except on rare occasions, ask states or persons independent of states whether they view an international organization as legitimate or not, why they do so, and whether and how such a perception may influence their future relation with the organization. Professor Tyler's Why People Obey the Law is of particular interest to the present inquiry because it is based on empirical research, the questioning of 1,575 citizens in the Chicago area. To the surprise of the domestic realists who tend to speak in terms of greater and more certain punishment as the prime determinant of compliance, Professor Tyler concludes:

People obey the law because they believe that it is proper to do so, they react to their experiences by evaluating their justice or injustice, and in evaluating the justice of their experiences they consider factors unrelated to outcome, such as whether they have had a chance to state their case and been treated with dignity and respect.

TYLER, supra note 19, at 178. Some of Tyler's conclusions arguably stem from human psychology generally, and others-perhaps most-seem deeply rooted in the social values of the study group. Thus, among the lessons to take from his work are the importance of the empirical approach and the conclusion that the perception of legitimacy was influenced significantly by whether there was procedural justice. 
within the full scope of its agenda?24 Or is the concern with illegitimacy overstated? Is the truth of the matter that the effectiveness of an institution such as the Security Council can withstand occasional perceptions of illegitimacy? As Haas observes, "States may grudgingly meet the organization's expectations without at the same time appreciating or valuing them." 25

Although a general account of the determinants of the significance of perceptions of illegitimacy is not available, one can hypothesize how such perceptions may bear on the effectiveness of an organization. Let me suggest five examples of how perceptions of illegitimacy may work against the effectiveness of the Security Council. First, they may lead to failure to pass a resolution-not necessarily because the underlying objective is questioned, but because of suspicion about the details and where it will lead. Second and more likely, such perceptions may lead to a refusal to adopt as strong a resolution. Third, they may make it difficult for states to build the domestic support necessary to act under a resolution. For example, because of such perceptions, a state may have trouble convincing its citizenry that granting landing rights to aircraft en route to a UN-authorized action is supportive of community concerns rather than the thinly veiled imperialism of the Council's permanent members. Fourth, such perceptions may lead states to move more slowly in supporting a resolution, in terms of the sending of troops, the provision of financial support, or the enforcement of embargoes. Fifth and last, such perceptions may lead either intentionally or accidentally to actions and strategies that weaken the Council. ${ }^{26}$

These possible scenarios are most likely if the perception of illegitimacy is held by a particularly influential actor or shared by a larger group of actors that in the aggregate are influential. Correspondingly, isolated allegations of illegitimacy by actors at the margin of an organization would likely have little significance for the

\footnotetext{
${ }^{24}$ Broadly speaking, a perception of illegitimacy might be said to affect the effectiveness of an institution in two ways. First, it might undercut the perceived legitimacy of the rules that emanate from the institution. Second, it might threaten the future effectiveness of the institution. Thus, the perceived legitimacy of the Security Council may influence both the willingness of states to obey and support particular decisions of the Council and its future use generally. This is particularly so when, as in the case of the Council, the organizational agenda itself is controlled primarily by the members and their disposition toward the setting of that agenda may be greatly affected by their perception of the legitimacy of the organization.

${ }^{25}$ HAAS, supra note 19 , at 87 . For a critical view of the practical significance of legitimacy, sec generally Hyde, supra note 19.

${ }^{26}$ As to the last possibility, it is worth recalling Claude's observation, supra note 2, at 368, that "[p]olitics is not merely a struggle for power but also a contest over legitimacy, a competition in which the conferment or denial, the confirmation or revocation, of legitimacy is an important stake." Over what alternatives, then, is there a "contest" in the case of the Security Council? One might conclude that if there is no viable alternative, an allegation of illegitimacy cannot be of much practical significance. See Habermas, Legitimation, supra note 19, at 178-79. But the lack of alternatives also may mean that the contest regarding legitimacy involves higher stakes for the organization involved and the issues before it. With no alternate route to promote, the contest ultimately may reduce to the rejection of contemplated action or pressure for reforms by the dissatisfied, not because they have an alternate order to propose, but because they simply desire to move away from the status quo. For their part, states now working through the Council, such as the United States and the United Kingdom, in turn may view the refusal of an ineffective Council as not being legitimate and, as a consequence, may return to the unilateral imposition of force or sanctions upon the allegedly offending state. See, e.g., Peter Wilenski, Reforming the United Nations for the Post-Cold War Era, in WHOSE New WORLD ORDER: What ROLE FOR THE UNITED NatTons? 122, 126 (Mara R. Bustelo \& Philip Alston eds., 1991). In both reactions-inaction at the multilateral level or action at the unilateral level—community objectives and tools are lost.
} 
organization as a whole. Assuming that there will always be some actor at the margin who calculatingly alleges that a certain means or act of governance is illegitimate, the issue becomes what influences whether such an allegation resonates with others more influential and thus may lead the allegation to take on greater significance. If actors at the margin often are the "root" of the allegation of illegitimacy, then the "echo" is how other actors, more central and influential, react upon hearing such an allegation. Given the existence of the root, the challenge for governance is to address the likelihood of substantial resonance with others. Given also that the identity of the speaker at the margin, for example, a terrorist state, likely is already discounted by the listener, the task is not to discredit the speaker, but rather to address what gives rise to the receptivity of the listener. ${ }^{27}$

From this perspective, an important question is: what circumstances influence the formation and course of such perceptions? ${ }^{28}$ Although the perception of illegitimacy with which we are concerned can spring from the taking of an illegal act, it often seems to arise from a deeper criticism of the organization. ${ }^{29}$ Even if an organization acts in accordance with its rules, it nonetheless may be viewed as illegitimate against some broader frame of reference. ${ }^{30}$

In one such frame of reference, allegations of illegitimacy appear to manifest a sense of betrayal of what is believed to be the promise and spirit of the organization." It is this promise and spirit that allows the organization collectively to ${ }^{27} \mathrm{~A}$ difficult aspect of the perception of illegitimacy is the difference in "sophistication" of the
different actors. On the one hand, officials with foreign ministries close to and involved with the Council might be thought to be the most sophisticated and tactical. That is, it might be thought that they would accept that the structure and operation of the Council is a matter of power, and indeed it is in that light that they quite consciously would frame their objections to such structure and operation in the language of legitimacy. But at whom is this initiative targeted? If this image of calculating actors is correct, then would not other actors close to the Council see through this ploy or simply discount it? Inasmuch as a substantial part of the critique of the Council turns on domination by the Permanent Five, and alludes to the closed nature of their deliberations and their imperialist pasts, perhaps the answer in the case of the Council, as in most cases, is that even the government representatives are a mix of the insider and the outsider simultaneously both discounting the language of legitimacy and being drawn to the values implicit in such phrasing.

${ }^{2 k}$ These questions form the core of the inquiry by FRANCR, supra note 19, which focuses on the legitimacy of rules. Interestingly, the inquiry appears to change slightly if one's focus is not on increasing the legitimacy of a rule, but rather on countering or anticipating an allegation of illegitimacy. Professor Franck's search for indicators of legitimacy is presumably motivated by a desire to increase the pull toward compliance of rules. However, because an allegation of illegitimacy may be merely a means to oppose an institution or rule, the dominant order does not seek so much to strengthen the pull toward compliance as to preserve the quantum of "belief" it already has.

${ }^{29}$ Weiler, Transformation, supra note 19, at 2468-69. "The notion of formal legitimacy . . . implies that all requirements of the law are observed ... . 'Social legitimacy,' on the other hand, connotes a broad, empirically determined societal acceptance of the system." Id.

3" See Claude, supra note 2, at 368-69 ("Lawyers tend simply to translate legitimacy as legality .... [But] the legitimacy of the positive law . . . is sometimes the precise issue at stake in a political controversy.").

"Although it often can be heard that the United Nations is only a collection of governments, a statement of the majority of the United Nations is for some reason taken as more than a statement of that same majority operating outside the United Nations. Turning that around, we seem to expect the United Nations to act differently than the same nations acting separately. We expect the United Nations, and other organizations of a universal character, to act consistently with the aura we give it.

For example, when the contributors to the International Monetary Fund require that borrowers undertake austerity measures before new loans are made, there is for some a concern regarding the legitimacy of the organization. On the other hand, if such conditions are requested in direct negotia- 
legitimate ideas or actions. Such collective legitimation at its worst masks, but in some cases perhaps limits, the extent to which particular actors pursue their own agenda under the banner of collective action. The loss of the perception of legitimacy is tied to loss of the ability to legitimate and consequently results in a reexamination of motives. "If the U.N. loses its credibility, the Security Council would still be able to order governments about, but its orders would have lost their international sheen and look more like big-power bullying." 39 All of these considerations suggest that, although international organizations are not world government and a realist's recognition of power is built into their constitutive documents, these organizations hold the promise of something more than politics as usual. ${ }^{33}$ Thus, I would argue that an important area within which perceptions of illegitimacy resonate in the case of international organizations is exemplified by that space between the promises of the preamble to the charter of the organization and the realities of the compromises in the text that follows, a space in which there is discretion regarding the use of authority. In this sense, the belief that there is too great a discrepancy between what the organization promises and what it delivers would be at least one major circumstance permitting the resonance of allegations of illegitimacy. Sometimes-and I would assert this is the case with the veto-the potential to betray the promise is built directly and tragically into the organization.

Similarly, the perception of illegitimacy may spring as easily from not acting as from acting. The critique of the Security Council at present focuses on the legitimacy of its use of authority. However, restricting its use of authority is not necessarily an answer because an ineffective institution in all likelihood would also be perceived-albeit perhaps by different states-as illegitimate. An institution is created for a purpose. To serve that purpose effectively, it is provided a measure of authority ${ }^{34}$ The failure of an institution to govern out of inability to use its

tions between one lender and one borrower, then that situation seems subject to at least a different legitimacy critique. The critique used for the international organization seems less applicable in the bilateral case because the power of the lender has not been clothed with the symbols of authority; there is no or little pretense of legitimacy to critique. In the bilateral case, we do not critique the cloak of legitimacy, but rather the motives of power.

${ }^{32}$ Open the Club, supra note 12, at 14.

${ }^{33}$ In particular, there is a promise of good faith and honest dealings with one another and in joint undertakings. 'As Leland Goodrich wrote:

[T] here is perhaps an excessive tendency today to view the United Nations simply as a set of organs and procedures made available to its Members in much the same way that various mechanical gadgets are offered to the public as means of making life easier. . . . Of much greater importance than the machinery itself are the basic commitments of Members, the purposes to which the machinery is put, and the spirit which governs its use.

LELAND GOODRICH, Korea: A STUdy OF U.S. POlicy IN THE UNITED Nations 2 (1956).

${ }^{34}$ For Professor HAAS, supra note 19, at 87, "authority consists of the ability of the organization to have its decisions implemented irrespective of the goodwill of the members concerned." Professor Weston asserts that Franck's notion of legitimacy "appears to be close to, if not identical with, the meaning of 'authority' as defined by Professors McDougal and Lasswell." Burns H. Weston, Security Council Resolution 678 and Persian Gulf Decision Making: Precarious Legitimacy, 85 AJIL 516, 516 n.1 (1991) (citing Myres S. McDougal \& Harold Lasswell, The Identification and Appraisal of Diverse Systems of Public Order, 53 AJIL 1, 9 (1959)). The many different ways in which these terms are employed in scholarly writings need be approached with care. Professors Haas and Franck apparently agree that "authority" signifies the ability of the organization to coerce compliance, while "legiti- 
authority, particularly an institution that represents or aspires to represent a system of order, has long been a basis for alleging that the order is illegitimate because it fails to perform its basic mission. The Council was created to be an effective mechanism for the maintenance of international peace and security, and to that end was granted substantial authority. At the same time, other values such as representation and cohesion of the international community informed the design of the institution that would use that authority. The perceptions of illegitimacy may thus arise from both the failure to use authority effectively and the abuse of authority. Consequently, one must seek an institution that simultaneously can employ its authority effectively and employs it in a manner that is regarded generally as legitimate.

These observations suggest that a basic challenge for international governance is to seek designs that promote institutional integrity, and that consequently address in the ordinary course of business the circumstances that make possible the resonance of allegations of illegitimacy. What are the characteristics of a process of decision with integrity, that may be trusted? How does one ensure that an institution is faithful to the promise of the organization, that is, that it acts with integrity? I would suggest that there are at least four ways.

First, in some instances integrity is promoted by entrusting operation of the organization to persons who can claim to be independent of those governed and to have no interest in a particular outcome. This approach is used to a degree, for example, with the International Court of Justice and the International Law Commission. It is not an option for the Security Council, where the member states are those governed. Second, states entrusted with the operation of the organization may be held accountable for the consequences of their actions. In particular, they may be politically accountable through elections; perhaps past failure to represent the members of the Assembly generally should be or has been a factor in the election of nonpermanent members of the Council. Third, an institution may also be accountable in that a court, an entity whose integrity is assured via independence, reviews the institution's decisions. But here, the competence of the International Court of Justice to review the performance of the Council appears to be quite circumscribed. ${ }^{35}$ Fourth, integrity may be promoted by providing the opportunity for representative participation and fostering an ongoing dialogue as to the legitimacy of any action. In other words, the discussion regarding legitimacy moves into the decision-making process itself.

These observations also suggest methodologically that an organization confronted with allegations of illegitimacy that strike a responsive chord in some quarters needs to identify what circumstances give rise to that resonance and how those circumstances might be addressed. Consequently, parts II and III respectively consider (1) what circumstances concerning the Council appear to provide the basis for resonance of questions regarding legitimacy, and (2) whether the proposed reforms address those circumstances. Part IV, in considering the reverse veto, seeks to promote integrity in the decision-making process by suggest-

macy" is evidenced at least in part by the willingness of those governed to comply or, I would assume, by the willingness of those governed to coerce compliance by their peers.

${ }^{35}$ See W. Michael Reisman, The Constitutional Crisis in the United Nations, 87 AJIL 83 (1993). But see Thomas M. Franck, The "Powers of Appreciation": Who Is the Ultimate Guardian of UN Legality?, 86 AJIL 519 (1992); and Geoffrey R. Watson, Constitutionalism, Judicial Review, and the World Conrt, 34 HARv. INT'L L.J. 1 (1993). 
ing practices that may further an ongoing dialogue as to the legitimacy of any particular action.

As it is both difficult and simplistic to characterize one's task as observation alone, so also is it simplistic to focus on the relation of process to perceptions of illegitimacy without considering the substance of what is being discussed in relation to those perceptions. As noted above, there is substantial work in progress on elaborating principled bases for intervention, and I believe that work on both the principles at play and the process of decision needs to be undertaken. I emphasize process in this article, however, because even in the face of agreement on the principles to be applied-and in many cases substantial agreement already exists-legitimacy concerns often arise in relation to the details of their application to a particular case. ${ }^{36}$ Successful outcomes will go far in painting over perceived defects in the process of decision. It is ultimately the process, however, that may allow participants who are somewhat distrustful of one another to believe in and support the organization.

\section{Challenges to the Legitimacy of the Security Council}

The Security Council through its decisions can both legitimate and legislate. It can legitimate the actions of others because it can purport to authorize those actions on behalf of the United Nations. It legislates in that its decisions potentially bind all states-both members of the United Nations that are not then sitting on the Security Council and states that do not belong to the United Nations at all. In short, the Council has substantial authority.

The current challenge to the legitimacy of the Security Council's use of that authority may be seen to have at least two major dimensions. Giving rise to each of these dimensions are a number of circumstances. Some of these circumstances are often discussed, others rarely mentioned, and one-crucially important in my view-has gone virtually unnoted. Although not wholly separate, the two broad dimensions of the challenge to the legitimacy of the Security Council's use of its authority reflect the perceptions (1) that the Council is dominated by a few states, and (2) that the veto held by the permanent members is unfair. The next two sections examine these two dimensions, ultimately identifying five circumstances that give rise to them. In considering these dimensions and circumstances, one should bear in mind the potential perception in the background referred to in part I; namely, a Council that fails to employ its authority effectively will also be viewed as illegitimate.

\section{The Perception of Dominance of the Council by a Few States}

A major charge against the Security Council is that it is dominated by several of the permanent members. ${ }^{37}$ Interestingly, although the Council's voting rules require that at least nine of the fifteen members must vote in favor of an action potentially binding all the members of the United Nations, it nonetheless suffers from the allegation of dominance by a subgroup of two, possibly three, or sometimes all five permanent members. ${ }^{38}$ At least ten, but most often thirteen or

\footnotetext{
${ }^{36}$ Accord Claude, supra note 2, at 369-70.

37 "America, Britain and France dominate decision-making; Russia is out of things and China intent on its own affairs." Open the Club, supra note 12, at 14.

${ }^{38}$ Childers, supra note 10, at 133 ("No longer is it morally possible for democratic people to accept that 5 out of 165 member governments can have such deadly power in the name of a peace-dedicated world organization.").
} 
fourteen, members of the Council voted in favor of all its recent decisions, but the legitimacy concerns expressed tend to focus on the United States, France and the United Kingdom. The assumption appears to be that, although Third World countries such as Colombia and Malaysia also voted in favor of the resolutions authorizing force against Iraq and were, with others, necessary to the passage of those resolutions, the Council is in fact dominated by certain members that, if motivated, can get a resolution adopted.

Thus, on the Libyan sanctions, Badi M. Ali, Chairman of the Islamic Committee for Palestine-North Carolina, wrote that "the United Nations has been brought in to do the dirty work of the British-American alliance against the Muslim world and third world countries." 39 As pointed out above, there will always be dissenting voices to the use of collective authority. What is important is whether such challenges to legitimacy, for whatever reason they are voiced, echo in the concerns of others. For example, the recent concerns of three U.S. political scientists do not conflict with, and could be said to support, the charge made by $\mathrm{Mr}$. Ali: "The real problem was that leadership turned into headship, where decisions for the group are arrived at unilaterally by a leader whose overweening power ensures that subordinates will have few other options than to comply."40 Or as Burns Weston observed, "the process by which Security Council Resolution 678 was won, while perhaps legally correct stricto sensu, confirms how complete the power of the United States over the UN policing mechanism had become in the absence of Cold War opposition."41

At first blush, it might seem that the need to have nonpermanent members, in a significant number of cases from the developing world, join the permanent members in voting for a particular measure would block dominance of the Council by one, two, or even five states. This statement presumes, however, that each member's decision about its vote is independent. Thus, one can imagine a member asserting that, even though its vote formally was needed for passage, the actual process of voting was dominated by a subgroup. Less extreme, and probably closer to the mark, would be the assertion that these nonpermanent members were broadly in agreement with the need to act, but not necessarily with all the particulars of the draft resolution. In this situation, dominance consists of the ability to push a certain proposal through to adoption.

Although not articulated by those concerned, this dominance can be seen as arising in three ways that should be carefully distinguished.

First, dominance can result from the power of the permanent members in international affairs generally. The power of the permanent members generally in the world potentially allows them outside the Council to influence the behavior of states within the Council. Professor Weston recounted, for example, various reports of U.S. promises of rewards and threats of punishment outside the Council so as to influence the vote on Resolution 678 authorizing the use of force against Iraq. ${ }^{42}$ Importantly, just as it is alleged that the United States in essence bought

\footnotetext{
${ }^{84}$ Ali, supra note 12.

40 Andrew F. Cooper, Richard A. Higgott \& Kim R. Nossal, Bound to Follow? Leadership and Fellowship in the Gulf Conflict, 106 PoL. ScI. Q. 391, 407 (1991).

1 Weston, supra note 34 , at 525 .

12 Id. at 523-25. His list includes the promise of financial help to Colombia, Côte d'Ivoire, Ethiopia and Zaire; agreement with the Soviet Union "to help keep Estonia, Latvia, and Lithuania out of the November 1990 Paris summit conference"; a pledge to the Soviet Union to persuade Kuwait and Saudi Arabia to provide it with desperately needed hard currency; and, to secure Chinese abstention
} 
votes, so is it as possible that some states demanded that their votes be bought. In any event, allegations of influence or demands outside the Council have not resurfaced in regard to the proceedings that followed the adoption of Resolution 678. In this sense, Resolution 678, and the urgency attached by the United States to its passage, may be the exception rather than the rule. However, the wielding of such power in international affairs need not be overt. It is generally in the interest of small states not to alienate the permanent members.

Second, dominance can result from the capabilities of the permanent members within the Council. The staffing capabilities of the permanent members within the Council allows them disproportionately to influence the outcome of its proceedings. The delegations of the nonpermanent members can simply be overwhelmed by delegations of members such as the United States. As in litigation where one side can afford what is relatively a vast amount of assistance, the initiative resides with those with the greatest capabilities. The other side is reduced to trying to respond to the initiatives of the more capable. Thus, the drafts under discussion are offered by permanent members, and the scheduling of meetings and informal discussions is quite naturally dominated by those most able to attend. The situation is aggravated substantially by the permanent members' practice of working out most decisions in informal consultations among themselves. ${ }^{43}$

This is not to say that the capabilities of certain states within the Council should be curbed dramatically. Indeed, given the hesitancy, if not passivity, of others, it can be strongly argued that if certain states did not draft and then push resolutions, nothing would be passed, and the organization would be ineffective. It is to suggest, however, that we need to look to how institutional structures may ensure that all the members of the Council play a role in its task of governance despite differences in capabilities.

Moreover, the relatively much stronger capabilities of the Permanent Five within the Council are accentuated even further when a sense of urgency focuses the Council's efforts on quick passage of a resolution. As has been apparent in the Council's action regarding the conflict in the former Yugoslavia, the longer a response is considered, the greater the influence of nonpermanent members can become. ${ }^{44}$ Also accentuating this aspect of dominance is the historical weakness of the Secretary-General as a referee in the Council acting to redress irnbalances in capability. ${ }^{45}$

Third, dominance by a group of states can result from disproportionate representation of that group on the Council. Representatives of states other than permanent

in the Council, agreement to lift trade sanctions in place since the Tiananmen Square massacre and to support a World Bank loan of $\$ 114.3$ million to China. Finally, Weston cites the report that, as a result of Yemen's negative vote on Resolution 678, the United States said it would cut off its $\$ 70$ million in annual aid to that state.

${ }^{43}$ See Reisman, supra note 35. See also Loie Feuerle, Note, Informal Consultation: A Mechanism in Security Council Decision-Making, 18 N.Y.U. J. INT'L L. \& POL. 267 (1985).

${ }^{44}$ See, e.g., Paul Lewis, U.N., With Abstention by Russia, Tightens Its Sanctions on Belgrade, N.Y. TIMES, Apr. 18, 1993, $\S 1$, at 1 (referring to the important role of Venezuela, Cape Verde, Morocco, Djibouti and Pakistan). However, in the case of the former Yugoslavia, the nonpermanent members not only had more time to develop their position, but also had greater room to maneuver since the permanent members were reluctant to take forceful action against Serbia.

${ }^{45}$ But the role of the Secretary-General is certainly evolving in a more active direction. See the range of discussion and proposals in THE CHALLENGING ROLE OF THE UN SECRETARY-GENERAL: MAKING "The MOST IMPOSSIBLE JOB IN THE WORLD" POSSIBle (Benjamin Rivlin \& Leon Gordenker eds., 1993). 
members sometimes maintain that the Council does not hold its authority legitimately because its composition is "not representative." This conclusion is reached often by a logic that one hopes is confined to the United Nations: Simply put, the argument runs that, since there are more states now than there used to be, there should be a corresponding proportional increase in the size of the Council. ${ }^{46}$ The more satisfying explanation is that, although a Council of fifteen could be "representative," the Council as currently constituted is not representative. Moreover, because it is very hard to redistribute the present membership pie, initiatives necessarily seek to regain representativeness through a remedial increase in the pie. Interestingly, representatives who express this view focus far more on "representation" than "dominance" even within the present scheme of representation, a circumstance likely explained by the fact that their prime motive is to increase the opportunity for membership on the Council.

Despite the possibility of such other motives for this position, the dominance of a group of states over the Council's proceedings certainly could be possible because of their disproportionate representation in the Council's membership. However, I do not think this possibility explains the dynamic now at work in the Council. As discussed more fully below, when present proposals for increasing the size of the Council are evaluated, they do not appear either to mitigate significantly the permanent members' dominance or to alter significantly the current distribution of representation.

\section{The Perception of Unfaimess Surrounding the Veto}

Concern over the veto has dominated discussion of the Council since its birth. The essential insight to be sought is how concern over the veto has been transformed by the end of the Cold War. Previously, the primary concern centered on how the veto prevented the Council from doing anything. The concern in the currently more active times has not been fully articulated, but I suggest that it has two aspects.

First, the five holders of the veto, and whatever states any of the five is willing to shield, potentially are free from the governance of the Council. Since for almost all of the Council's existence it did not act, the freedom from governance of some was not a significant problem because few states, if any, were governed by it. ${ }^{47}$ But as the Council begins to function, the question becomes: are there states that will be governed and states that will not? The ability of the Security Council to take decisions binding on the community as a whole in the area of peace and security is a strong form of governance. The veto means, however, that certain members of the community potentially are not governed. In the context of the Council's actions in response to Iraq's invasion of Kuwait, the question for many became: is there a double standard-will the Council be as assertive with Israel as it was with

\footnotetext{
4h Another argument raised is that, inasmuch as the Council has more work to do, it should have more members. To the contrary, more members might only generate more work in terms of coordination, and more work seems to suggest a need for an increase in staff rather than membership.

47 It is of course a simplification to say there was no governance or no concern with double standards prior to the recent activity of the Council. Previously, the charge of a double standard generally involved the willingness of UN members to criticize the West and Israel, but not socialist or other Third World states. See Thomas M. Franck, Of Gnats and Camels: Is There a Double Standard at the Unuted Nations?, 78 AJIL 811 (1984); Theo van Boven, Letter to the Editor, 79 AJIL 714 (1985).
} 
Iraq $?^{48}$ When the Council acted against Libya, the question became: is it only the Arab world that is so governed? There is no simple answer to these questions, but the permanent presence of some members, with vetoes, clearly gives a privileged position to a few.

Second, the veto distorts any governance undertaken because it severely limits the basis of possible discourse. Such distortion is discussed in detail in part IV. What is important to see here is that this impact of the veto reinforces the perception and reality of dominance of the Council by the permanent members.

\section{The Five Challenges}

There are thus five challenges to the legitimacy of the Council's use of its authority:

- The perception of dominance of the Security Council by a few states

1. Dominance because of the power of those states in international affairs generally

2. Dominance because of the capabilities of those states within the Council

3. Dominance because of the disproportionate representation of those states on the Council

- The perception of unfairness surrounding the veto

4. Unfairness because of the possibility of a double standard in governance

5. Unfairness and dominance because of the disabling effect of the veto on the sense of participatory governance

\section{Evaluating Proposals for Reform}

Having sketched the circumstances that give rise to perceptions of illegitimacy, I consider in this section the degree to which suggested reforms might rectify the problem. This task is particularly important because the motives behind some of the reform proposals have little to do with remedying the circumstances underlying concerns about legitimacy.

Ideally, reform should promote the international community's objective in the Council: an effective mechanism for the maintenance of international peace and security. ${ }^{49}$ And, as asserted in part $\mathrm{I}$, the perception of legitimacy regarding the authority necessary for such a mechanism is desirable for both short- and longterm effectiveness. Now that the Council is acting, legitimacy arguably is essential

\footnotetext{
${ }^{48}$ See, e.g., Youssef M. Ibrahim, Many Arabs See "Double Standard," N.Y. Times, Jan. 15, 1993, at A8; Clyde Haberman, And Even Some Israelis Agree With Them, id. See also Childers, supra note 10, at 136 ("[I]t has been the blatant use of double standards in the invocation of UN principles against Iraq that has so eroded the confidence of the Southern majority of humankind in the world organization."). A more diplomatic and positive phrasing of the question can be found in the statement of the Colombian representative before the Council as Resolution 678 authorizing the use of force against Iraq was adopted: "We hope that this climate of understanding will be maintained and will serve as a basis for the decisions that the Security Council may have to take in the future so as not to have its credibility and effectiveness tarnished through use of a double standard . . . ." UN Doc. S/PV.2963, at $38(1990)$.

${ }^{49}$ This objective is evident in the language and drafting history of the UN Charter. See, e.g., UN CHARTER Art. 24 ("primary responsibility for the maintenance of international peace and security, and . . . carrying out its duties [on behalf of the members]").
} 
to ensuring its long-term effectiveness. But just as it seems wrong to gain effectiveness at too great an expense to legitimacy, so does it not make sense to increase legitimacy at the expense of a significant loss in effectiveness. Thus, I will argue, for example, that we should take care in rushing to increase the size of the Council. That states individually desire the status of membership and propose expansion does not mean it makes sense collectively. The Council could probably expand somewhat without significantly decreasing its effectiveness. The issue, however, is: how much could it expand without such a loss? Would a Council of twenty-five members remain effective or would we see the emergence of the unending procedural spirals seemingly endemic to the Second Committee of the General Assembly? As calls for increased membership and other proposals are considered, the relationship of power and legitimacy to effectiveness must be kept in mind.

The fundamental question is: how should the decision-making authority of the Security Council be allocated so as to maximize the effective use of its authority and the perceived legitimacy of that use? The powerful presence of the veto, however, has tended to capture attention in a way that misplaces the focus of both the academic and the diplomatic worlds. Simultaneously, the driving force behind diplomatic concerns often seems to be more the preservation and attainment of status than the efficacy and legitimacy of collective decision. It is the latter concern that falls to the academy. The proposed reforms tend to fall into three broad categories, which will be considered in turn.

\section{Reform of the Veto}

Practically speaking, it is quite unlikely that the veto can be eliminated or even significantly limited. Moreover, if one's goal in reforming the veto is to mitigate the possibility of a double standard in governance, any substitute voting procedure will in all likelihood allow some sort of double standard to continue.

The voluminous literature on the Security Council has several branches. A review of these branches helps one to understand why the permanent members of the Council possess a veto and why they probably will continue to do so.

The first branch: the debate over the wisdom of granting vetoes to some states. Much of the early literature focused on the decision to grant a veto to some members of the Council. Initially, this branch revisited the negotiation of the relevant Charter provisions. The negotiation was a matter of politics and, as $\mathrm{E}$. $\mathrm{H}$. Carr would say, consequently involved a confrontation between utopia and reality, morality and power. ${ }^{50}$ The permanence of membership of a few and, even more, the veto of those permanent members were perceived from the outset by some states as a threat to the legitimacy of the Council's authority.

The significance of membership and voting procedures in international organizations depends directly on the powers of the body and the importance of the issues that will come before it. The importance attached to the structure of the Security Council during the preparation and drafting of the Charter flowed from the recognition that the Council would have both "primary responsibility for the maintenance of international peace and security" and the authority to carry out that responsibility. Agreement among the Allies at Dumbarton Oaks in 1945 on the number of members and the permanent membership of the five major Allied powers did not resolve the question of voting, and the issue in particular became

\footnotetext{
${ }^{50}$ CARR, text at and note 1 supra.
} 
"how to balance what might be called 'democratic' procedures with the realities of the concentration of power among the five permanent members." 51 There was a range of possibilities:

the inclusion in any affirmative vote of a stated majority of the permanent members, such as three-fifths or four-fifths; the inclusion of two or three of the strongest powers indicated by name; the stipulation of a majority made up of a certain proportion of both the permanent and the non-permanent members; the requirement of unanimity among the great powers plus enough votes of the smaller powers to prevent "dictation" by either group over the other. ${ }^{52}$

The Dumbarton Oaks Conference settled on the last option, requiring a majority of seven of the eleven members (today nine of fifteen), the seven to include the permanent members except with regard to procedural matters. ${ }^{53}$

The work of the Dumbarton Oaks Conference, as elaborated on at Yalta in February 1945, was the starting point for negotiations at the United Nations Conference on International Organization held in San Francisco in May and June of 1945. The proposed voting procedure of the Council was the subject of extensive negotiation, as seventeen of the forty-four states present offered amendments to it. Faced ultimately with the belief that the conference would fail if any other voting procedure was chosen, the participants adopted the Yalta formula. ${ }^{54}$

The debate over the wisdom of this initial decision can be found in much of the literature. At its core, the debate sets "internationalists," who in essence opposed the veto as a superpower obstacle to a truly functioning United Nations, against "realists," who viewed the agreement of each of the major powers as politically wise and necessary to the undertaking of action by the Security Council.

The second branch: the veto in practice. The existence and likely continuation of the veto produced an offshoot of the first branch, the study of the use of the veto. At first, this was an extension of the internationalists' literature, focusing on what many regarded as the abusive obstructionary use of the veto and possible mechanisms for limiting that use. Indeed, the veto quickly proved to be much more of a problem than even the more pessimistic of the delegations at the San Francisco Conference had probably foreseen. ${ }^{55}$ One abusive phenomenon particularly stud-

\footnotetext{
${ }^{51}$ Dwight E. Lee, The Genesis of the Veto, 1 INT'L ORG. 33, 35 (1947).

52 Id.

${ }^{53}$ Left unresolved at Dumbarton Oaks and preventing agreement generally on voting at that time was whether a member, particularly a permanent member, of the Council could vote when it was a party to the dispute under consideration. The recent experience of the League of Nations, particularly the vote of Italy blocking action against it under Article 11 of the Covenant, loomed large. In February 1945 at Yalta, a compromise formula was agreed upon by the United States, the United Kingdom and the Soviet Union: a member of the Council that was a party to the dispute under consideration would abstain from voting in efforts at peaceful settlement (what came to fall under chapter VI of the Charter) or efforts to encourage such settlement by regional arrangements or agencies (Article 52(3) of the Charter). This meant, however, that the member need not abstain from voting when stronger measures aimed at peace enforcement were contemplated (what came to be governed by chapter VII of the Charter).

54 The fight during the negotiations, however, did yield the oft-cited and much-debated Statement by the Delegations of the Four Sponsoring Governments on Voting Procedure in the Security Council, explaining their understanding of the Yalta formula. See, e.g., Leo Gross, Double? Veto and the Four-Power Statement on Voting in the Security Council, 67 HARv. L. REv. 251 (1953).

55 Although Sydney Bailey asserts that "the United Nations has been hamstrung by the veto neither as frequently nor as decisively as has sometimes been suggested." SYDNEY BAILEY, VOTING IN THE SECURITY Council 62 (1969).
} 
ied was the "double veto." Article 27 of the Charter establishes two voting procedures, one for procedural matters and one for "all other matters." The existence of two voting procedures necessarily engenders a "border" question, that is, which of the procedures applies in a given situation and which voting procedure is to be used to decide that preliminary question. The double veto was the term coined for the employment of the veto to block the characterization of any question as "procedural." 56

The main limitations on the scope of the veto involved the decision in practice to regard abstentions or the failure of a permanent member to vote as a "concurring vote, ${ }^{57}$ and the effort by the General Assembly in the early years of the Organization to limit the range of subject matter to which the veto was applicable. ${ }^{58}$

More recently, the study of the veto in practice has seen an increase in empirical examination of its use, ${ }^{59}$ a trend that in all likelihood reflects the ultimately discouraging recognition that the veto is essentially immune from reform.

The third branch: the difficulty of amending the Charter. The difficulty of amending the Charter, and hence reforming the veto, can be taken to explain the evolution of the literature. This difficulty also may explain why this third branch of the literature is comparatively a trickle, ${ }^{60}$ although it should not justify the absence of scholarly attention.

Basically, the internationalists, in seeking to alter the veto practice, needed to call for an amendment to the Charter, and the unlikelihood of success in this regard ultimately led their debate with the realists to recede to the margins of discourse. The debate became dormant largely because there appeared to be little chance that the permanent members would ever relinquish the veto. To call for

${ }^{5 \hbar}$ See Alexander W. Rudzinski, The So-Called Double Veto, 45 AJIL 443 (1951); Marion K. Kellogg, The Laos Question: Double What Veto?, 45 VA. L. Rev. 1352 (1959); Leo Gross, Question of Laos and the Double Veto in the Security Council, 54 AJIL 118 (1960) (Editorial Comment); Alan R. Feldstein, Comment, The Double Veto in the Security Council: A New Approach, 18 Buff. L. Rev. 550 (1968-69); and Franciszek Przetacznik, The Double Veto of the Security Council of the United Nations: A New appralsal, 58 Revue de Drotr International de Sciences Diplomatiques, Politiques et SoCLALES 153 (1980).

${ }^{57}$ See Yuen-li Liang, Abstention and Absence of a Permanent Member in Relation to the Voting Procedure in the Security Council, 44 AJIL 694 (1950); Myres S. McDougal \& Richard Gardner, The Veto and the Charter: An Interpretation for Survival, 60 YALE L.J. 258 (1951); Leo Gross, Voting in the Security Council: Abstention from Voting and Absence from Meetings, id. at 209; Constantin A. Stavropoulos, The Practice of Voluntary Abstentions by Permanent Members of the Security Council Under Article 27(3), 61 AJIL 737 (1967); Sydney Bailey, New Light on Abstentions in the UN Security Council, 50 INT'L AFF. 554 (1974); and Charles G. Nelson, Revisionism and the Security Council Veto, 28 INT'L ORG. 539 (1974).

${ }^{54}$ See Francis $\mathrm{O}$. Wilcox \& Carr M. Marcy, Proposals for Changes in the United Nations 317-19 (1955); BAILEY, supra note 55, at 48-52, 112-35.

${ }_{54}$ See, e.g., ANJALI V. PATIL, The UN VETO IN WORLd Affarrs 1946-1990 (1992); James E. Todd, An Analysis of Security Council Voting Behavior, 22 W. PoL. Q. 61 (1969); and Robert S. Junn \& Tong-Whan Park, Calculus for Voting Power in the UN Security Council, 58 Soc. ScI. Q. 104 (1977).

${ }^{60}$ See, e.g., Egon Schwelb, Amendments to Articles 23, 27 and 61 of the Charter of the United Nattons, 59 AJIL 834 (1965); idem., The 1963-1965 Amendments to the Charter of the United Nations: An Addendum, 60 AJIL 371 (1966); idem., The Amending Procedure of Constitutions of International Organizations, 31 BRIT. Y.B. INT'L L. 89 (1954); idem., Charter Review and Charter Amendment: Recent Developments, 7 INT'L \& CoMP. L.Q. 303 (1958); idem., The Question of a Time Limit for the Rattfication of Amendments to the Charter of the United Nations, 4 INr'L \& COMP. L.Q. 475 (1955); Emile Giraud, La Revision de la Charte des Nations Unies, 90 RECUEIL DES Cours 311 (1956 II); Jyrki Kivisto, Amendments to the Charter of the United Nations (1968) (unpublished LL.M. thesis, University of California at Berkeley). 
amending the Charter on the subject of the veto came to be viewed as naive. To some degree, it would still be regarded as naive. Indeed, Sydney Bailey, a leading authority on the Council, wrote in 1992 that "I know of no evidence that any of the five permanent members is at present willing to give up the right of veto." 61 Thus, it is not surprising that empirical studies in recent years came to prevail in the literature on the veto.

Ernst Haas has emphasized, however, that many events that until quite recently were thought highly unlikely - such as the fall of the Berlin Wall and the breakup of the Soviet Union- - have come about and so, too, may the permanent members be convinced in the not-so-distant future to relinquish the veto. ${ }^{62}$ Moreover, he stated, it is the place of the academy to prepare for this possibility, to devise the alternative arrangement of voting that will both facilitate such a change and make it successful. His return to the basic issues is welcome and appropriate, although he probably would agree that how the willingness of the permanent members to relinquish the veto might arise is as yet unclear.

Procedurally, the permanent members have a veto over any effort to take away their right of veto. ${ }^{63}$ Thus, both the foreign ministries and the entities involved in the domestic ratification process of all the permanent members must concur in an amendment to do away with or limit the veto. In some ways, this provision was objected to even more than the veto itself at the San Francisco Conference in $1945 .^{64}$

Let us, despite the difficulty of amendment, assume for a moment that the new U.S. administration asked for an assessment of whether the United States should seek to eliminate the veto. What would that assessment be? What would the United States gain by relinquishing the veto? The primary gain would be the relinquishment of the veto by all the other permanent members and thus assurance that the Council would not fall back into the paralysis that gripped it during the Cold War. How much gain is that? If the Council were once again to be paralyzed, could not the United States simply return to the unilateral imposition of sanctions or force? The United States, for example, reportedly wrote in December 1992 to President Slobodan Milošević of Serbia that, "[i]n the event of conflict in Kosovo caused by Serbian action, the United States will be prepared to employ military force against the Serbs in Kosovo and in Serbia proper."65 De-

\footnotetext{
${ }^{61}$ Sydney Bailey, The Security Council, in The United Nations and Human Rights 304, 324 (Philip Alston ed., 1992).

${ }^{62}$ Ernst Haas, Will the New UN Lead Us to a New World Order?, lecture delivered at the Institute of International Studies, University of California at Berkeley (Nov. 2, 1992).

${ }^{63}$ Article 108 of the Charter provides:
}

Amendments to the present Charter shall come into force for all Members of the United Nations when they have been adopted by a vote of two thirds of the members of the General Assembly and ratified in accordance with their respective constitutional processes by two thirds of the Members of the United Nations, including all the permanent members of the Security Council. (Emphasis added)

To the same effect, see UN CHARTER Art. 109(2).

${ }^{64}$ See Goodrich, Hambro \& SMmons, supra note 3, at 638-39.

${ }^{65}$ David Binder, Bush Warns Serbs Not to Widen War, N.X. Times, Dec. 28, 1992, at A6; see also Elaine Sciolino, Aides Give Clinton Bosnia Peace Plan, N.Y. Times, Feb. 9, 1993, at A14 (reiteration by Clinton administration of warning to Serbia by Bush administration). This warning, however, although forceful, is not without ambiguity as to whether UN authorization for such a use of force would be sought. See also Douglas Jehl, U.S. Turns Bosnia Threat Into a Near Ultimatum, N.Y. TIMES, Aug. 4, 1993, at Al. 
spite the fact that it could return to unilateral action, the assistance the United States gains through the Security Council's collective legitimation of an action should not be minimized. Authorization to board ships so as to enforce a regime of sanctions, for example, was an important aid in both the Iraqi and the Serbian cases-and a provision whose loss at the last moment was particularly noted in the Haitian case. ${ }^{66}$ Similarly, the request that all states aid those states acting in concert with Kuwait during the Persian Gulf war reportedly eased the way for the United States in several instances. ${ }^{67}$

What is lost by relinquishing the veto? The United States becomes subject, like everyone else, to the governance of the Security Council. But we must bear in mind that an alternate, and probably quite complicated, voting arrangement would replace the present one; the United States, while lacking a veto, would likely need only a few other votes to protect itself. Yet we might ask why the United States might feel the need to shield itself absolutely from such governance, i.e., do we anticipate acting in such a manner that even our closest allies would not vote with us? This brings us to the one advantage that probably would be lost, namely, the ability to shield Israel from the governance of the Council. Here, hope for relinquishment of the veto resides in the possibility that a general settlement in the Middle East may not be far off.

Assuming that the United States would be convinced by analysis along the lines stated above, could the international community induce the United Kingdom, France, Russia and China to make similar moves? China, absorbed with maintaining internal order, would likely oppose relinquishing its veto (although, here too, fundamental change may not be that far off). Moreover, if Russia recalls its desire to shield Serbia from stronger Council actions in the spring of $1993^{68}$ and China recalls its opposition during the same period to Council sanctions against North Korea because of likely nuclear proliferation, ${ }^{69}$ both may oppose relinquishment of the veto.

Yet even if elimination of the veto altogether is not possible, it may be possible to limit its use. Significant limitations likely would run into the obstacles posed above. Perhaps a feasible limitation would be to eliminate the veto in the election of the Secretary-General.

In sum, despite the calls for change, it must be recognized that it will be difficult to amend the Charter, particularly if the amendment seeks to eliminate the veto or restrict it in any significant way. Consequently, the pressures for change in

\footnotetext{
${ }^{n 6}$ French, supra note 7. Such authorization was also of concern in the case of Southern Rhodesian sanctions. See Vera Gowlland-Debbas, Commentary on the Report on the Use of Economic Sanctions by the UN Security Council (presented at the Second Verzijl Symposium, Feb. 19, 1993).

${ }^{67}$ Paragraph 3 of SC Res. 678, supra note 14, "[r]equest[ed] all States to provide appropriate support for the actions undertaken in pursuance of paragraph 2." Officials involved with Operations Desert Shield and Desert Storm indicated to the author that this provision was helpful in gaining rights of overflight and permission for landing and refueling of aircraft.

${ }^{68}$ See Paul Lewis, U.S. Seeks Tougher Sanctions on Yugoslavia, N.Y. Trmes, Apr. 7, 1993, at A6; Paul Lewis, Security Council Delays Action Against Serbs, N.Y. TIMrs, Apr. 13, 1993, at A8; Elaine Sciolino, U.S. Agrees to Delay in Voting on Serbia Sanctions, N.Y. Trmes, Apr. 13, 1993, at A9; Paul Lewis, Russians Resisting Tighter Sanctions Against Belgrade: May Thwart Vote at U.N., N.Y. TIMEs, Apr. 9, 1993, at Al; Paul Lewis, Russia Seeks to Delay Vote on Belgrade Sanctions, N.Y. Times, Apr. 12. 1993, at A8; Michael Gordon, Russia Declines to Support Tighter Sanctions on Serbia, N.Y. TIMEs, Apr. $18,1993, \S 1$, at 8 .

${ }_{69}^{6 y}$ See Nicholas D. Kristof, China Opposes Sanctions in North Korea Dispute, N.X. Times, Mar. 24, 1993, at A8; and Nicholas D. Kristof, China and North Korea: Not-So-Best Friends, N.Y. TIMES, Apr. $11,1993, \$ 4$, at 4 .
} 
the decision-making process in the Security Council will likely focus on other proposals, in particular expansion of its membership.

\section{Increasing the Membership of the Security Council}

Most of the proposals for reform have been directed at dealing with the perceived imbalance in control of the Council, in particular its alleged domination by the West. In the main, however, these proposals do not seek to curb the strength of the West in the process but, rather, somehow to increase the strength of others.

Thus, one line of proposals calls for an increase in the size of the Council, in many cases with permanent status being given to the major regional powers in the developing world. Former Soviet President Mikhail S. Gorbachev, in his 1992 address at Westminster College, the site of Winston Churchill's "Iron Curtain" speech, advocated expanding the Security Council to include such states as India, Japan, Poland, Mexico, Germany, Brazil, Canada, Indonesia and Egypt. ${ }^{70}$ Shortly after taking office, the Clinton administration indicated that "it favors allowing Germany and Japan to have permanent seats," "71 and this past June informed them that it would soon start a campaign to that end. ${ }^{72}$ Numerous other calls for similar expansions of the membership have been made, ${ }^{73}$ some of them over a decade ago. ${ }^{74}$ The General Assembly is expected to hold a major debate on increasing the Council's size in the fall of $1993 .^{75}$

With the purpose of the Security Council and the memory of the League's experience in mind, the delegates to the United Nations Conference on International Organization generally accepted that the Council's membership should be representative of the entire membership, yet also able to summon up the concerted military power of the international community. ${ }^{76}$ Ultimately, the Charter as agreed upon in San Francisco provided that the six nonpermanent members of the eleven-member Council would be elected for a term of two years by the

\footnotetext{
${ }^{70}$ Francis X. Clines, At Site of "Iron Curtain" Speech, Gorbachev Buries the Cold War, N.Y. TimEs, May 7, 1992, at Al.

71 Paul Lewis, U.S. Backs Council Seats for Bonn and Tokyo, N.Y. TIMES, Jan. 30, 1993, at 4.

${ }^{72}$ Paul Lewis, U.S. to Push Germany and Japan for U.N. Council, N.Y. TIMES, June 13, $1993, \S 1$, at 7 .

${ }^{73}$ See, e.g., Martín C. Ortega Carcelén, La Reforma de la Carta de Naciones Unidas: Algunas Propuestas Institucionales, 43 Revista EsPaÑola DE DERECHO INTERNACIONAL 389, 400 (1991) (recommending the addition of India, Germany and Japan).

${ }^{74}$ As Australia's Permanent Representative to the United Nations wrote:

[D]uring the 1979 General Assembly India proposed that the non-permanent members be expanded from ten to fourteen, with the four extra to come from the African Group (up from two to five), and the Asian and Latin American Groups (both up by one to three). All the Permanent Five except China were opposed to any expansion.
}

Wilenski, supra note 26 , at 126.

${ }^{75}$ Lewis, supra note 72.

${ }^{76}$ At the Dumbarton Oaks Conference in 1945, the memory of the inability of the League of Nations to act decisively against Italy impressed upon the delegates that the Council must be small enough as not to be unwieldy and that the requirement of unanimity-even in such a small groupwould likely render the Council ineffective. As to the drafting history of the membership and voting structure of the Security Council, see Francis O. Wilcox, The Rule of Unanimity in the Security Council, 40 ASIL Proc. 51 (1946); James B. Reston, Votes and Vetoes, 25 ForEIGN AFF 13 (1946); B. A. Wortley, The Veto and the Security Provisions of the Charter, 23 BRIT. Y.B. INT'L L. 95 (1946); Hans Kelsen, Organization and Procedure of the Security Council of the United Nations, 59 HARv. L. REv. 1087 (1946); Yuen-li Liang, The Settlement of Disputes in the Security Council: The Yalta Voting Formula, 24 BRrT. Y.B. INT'L L. 330 (1947); and Lee, supra note 51. 
General Assembly, with "due regard being specially paid, in the first instance to the contribution of Members of the United Nations to the maintenance of international peace and security ... . and also to equitable geographical representation." "77 The membership of the Council was increased to its present level of fifteen in 1963 by raising the number of nonpermanent members from six to ten. ${ }^{78}$

The new proposals seek to increase the Council again, this time perhaps quite substantially. Often a total of twenty members is sought; occasionally, as many as twenty-five. But how do such proposals further the objective of maximizing both the effectiveness and the legitimacy of the Council?

Would an increase in membership lead to a stronger perception of legitimacy? Why should we think that having more states would lead to less domination? One way that increased membership results in less domination of the process is by reducing the frequency of turns for the permanent members to fill the rotating presidency of the Council. This effect concerned the permanent members at the time of the last increase in the Council's size. ${ }^{79}$ But increased membership otherwise might not increase perceptions of legitimacy. If Colombia and Malaysia cannot at present be said to represent the developing world, would the addition of three more representatives of the developing world do so? Or would it simply increase the number of countries the United States would need to convince to go along with a resolution? What is it that makes a nonpermanent member of the Council also a representative of the remaining members of the Assembly?

Moreover, as mentioned, many of the proposals to increase the membership are aimed at bringing particular states into the Council. The permanent addition of Germany and Japan would only seem to strengthen the ability of the permanent members to dominate the Council: Germany and Japan presumably would participate in informal consultations; they would bring their power in international affairs with them, which could influence the disposition of the nonpermanent members; and they would add their staffing capabilities to those of the present permanent members. In addition, if the other new members are regional powers, then representation, at least in terms of representing the perspective of small states, would not be increased. Indeed, such representation would, by dilution, be decreased.

Will an increase in membership lead to a loss in effectiveness? Referring to the several increases in membership of the Council of the League of Nations, E. H. Carr wrote: "The Council, in becoming more 'representative', lost much of its effectiveness as a political instrument. Reality was sacrificed to an abstract principle." 80 Echoing this concern, the Permanent Representative of Australia to the United Nations recently wrote that "[p]erhaps the greatest drawback in making the Council more representative is the practical risk that a significantly enlarged Council would make decision-making more difficult."81 Several close observers of the United Nations consider this "practical risk" to be quite high. Michael Reisman recently wrote that "expansion of the Council would be unlikely to satisfy those agitating for change, yet it would make the Council more unwieldy

\footnotetext{
${ }^{77}$ UN CHARTER Art. $23(1)$.

is As to the amendment, see Leo Gross, Voting in the Security Council: Abstention in the Post-1965 Amendment Phase and Its Impact on Article 25 of the Charter, 62 AJIL 315 (1968).

${ }^{7 y}$ See Davidson Nichol, The United Nations SeCurtTy Council: Towards Greater EFfectiveNESS $16-17$ (1982).

"' CARR, supra note 1, at $29 . \quad \quad 31$ Wilenski, supra note 26 , at 127.
} 
and less efficient." 82 Similarly, Brian Urquhart observed that an increase in the membership of the Council would reduce its effectiveness. ${ }^{83}$

Is it possible that this concern about effectiveness is overstated? Could the entire image of impending doom in the form of a loss of effectiveness itself be a result of dominance? Does the language of the dominant influence even the way we talk about and analyze the situation? This possibility, intriguing as it is, seems misplaced at least in the sense that at some point an increase in the size of the Council would inevitably reduce its effectiveness. Thus, the question becomes the point at which this limit is reached. Moreover, one must recall that some states desire an increase in membership not because they necessarily seek an effective Council but because they understandably seek the status of membership. As importantly, those few rogue states that fear the Council may threaten the continuance of their rule may support increased membership precisely because they believe it will reduce the Council's effectiveness.

All of these considerations point to the importance of thinking through the need for strengthening the relationship of the Council to the Assembly generally and adding members as appropriate to solidify that relationship without also weakening either the effectiveness or the legitimacy of the Council. Since there are reasons why it may not be wise to increase the membership, we would do well to recall the precedent for informal mechanisms that do not require amendment of the Charter and may go far toward satisfying demands for fundamental change. An example of how such informal changes work can be found in the United Nations budgetary process. The Charter provides that the budget shall be approved by the General Assembly by a two-thirds majority vote. ${ }^{84}$ However, in response primarily to a U.S. demand for change, the operational, though informal, budgetary process now is one of consensus. ${ }^{85}$ This process is not legally guaranteed through enshrinement in the Charter. But its operation, however temporary, eliminated a major objection to the United Nations and took the wind out of extremists' arguments in the United States that it should withdraw from the Organization. Similarly, the pressure for fundamental change in the Security Council could be diminished by satisfying some of the demands of the states in question. The desire of Germany and Japan for more influence on the Council could be met in part by informally granting them a significant role in decision making or by informally ensuring that one or both of them are placed on special Council committees. For example, Japan has wielded great influence, if not a veto, in the United Nations Transitional Authority in Cambodia because its involvement is essential to the financial viability of the effort; it is maintaining this influence through membership on the International Committee on the Reconstruction of Cambodia. ${ }^{86}$ Similarly, the Council could offer the promise of increased consultations with regional powers such as India, Nigeria, Brazil and Egypt.

\footnotetext{
82 Reisman, supra note 35, at 96.

${ }^{83}$ Brian Urquhart, Remarks, 87 ASIL Proc. (1993) (forthcoming). See also Rochelle Stanfield, Worldly Visions, NAT'L J., Oct. 27, 1990, at 2597, 2600 (reporting many experts to believe the Council would be rendered unwieldy).

${ }^{84}$ UN Charter Arts. 17(1), 18(2).

${ }^{85}$ As to the meaning of consensus in this context, see Erik Suy, Consensus, in [Installment] 7 ENCYCLOPEDIA OF PUBLic INTERNATIONAL LAW 49 (1984).

${ }^{86}$ See Yuli Ismartono, Cambodia: Continued Factional Rivalry Impedes Peacekeeping Mission, Inter Press Service (Apr. 15, 1992), available in LEXIS, Nexis Library.
} 


\section{Increasing the Involvement of the General Assembly}

The final line of reform proposals seeks to open up Council proceedings to the General Assembly and thus increase the sense of participatory governance and in some measure create political accountability for members of the Council. The premise motivating these proposals is that the decision making of the Security Council takes place in informal consultations that increasingly involve only a subgroup of its membership and that consequently exclude not only the nonpermanent members but the membership generally. Thus, it has been proposed:

- that the Assembly acquire its own "watch and alert" capacities by increasing the size of the office of its President;

- that the Assembly be permitted to evaluate and criticize the efforts of the Security Council to maintain international peace and security; ${ }^{88}$

- that the prohibition in the Charter on the immediate reelection of nonpermanent members be lifted; ${ }^{89}$

- that the Secretary-General be authorized to notify the Assembly of disputes and situations "being dealt with" by the Security Council;" and

- that a "Chapter VII Consultation Committee" be created, to be composed of twenty-one members of the Assembly representing a range of regions and interests, and to be notified by the Council whenever it contemplates action under chapter VII. ${ }^{91}$

Some of these proposals tend to be "top down" efforts to involve the broader membership, e.g., the creation of a consultation committee. Others assume that efforts to ensure greater participation will bubble up from the bottom and thus seek to remove barriers to participation, e.g., removal of the ban on immediate reelection. To the extent that the legitimacy concerns described above are indeed widespread, we should encounter increased bottom-up demands on the nonpermanent members by those outside the Council at any given time. For example, in electing nonpermanent members to the Council, the General Assembly may come to place greater value on the willingness and ability of the candidate state to consult with members of the United Nations generally or with a specific subgroup they might be said to represent.

\section{Do the Proposals Remedy the Circumstances Underlying Legitimacy Concerns?}

Unfortunately, the proposals often suggested have only a modest effect on the circumstances giving rise to legitimacy concerns about the collective authority of the Council. As far as the potential double standard in governance engendered by

\footnotetext{
${ }^{87}$ Childers, supra note 10, at $134 . \quad{ }^{88}$ Ortega Carcelén, supra note 73, at 400-02.

${ }^{*}$ Sce, e.g., Ramesh Thakur, The United Nations in a Changing World, 24 SECuRITY DIALOGUE 7, $13(1993)$.

an The Secretary-General under Article 12(2) of the Charter currently needs the consent of the Council to so notify the Assembly. See Childers, supra note 10, at 134; see also Reisman, supra note 35 , at 98 .

9) Reisman, supra note 35 , at $98-99$.
} 
the veto is concerned, it is unlikely that the veto will be eliminated in the near future. Moreover, any voting procedure that would replace the present one would be complex and involve some form of weighted voting. Thus, a weaker form of double standard in governance would likely persist. However, since the trigger of this weaker double standard would not be within the discretion of a single state and its use would in any event be less obvious, the perception of illegitimacy would probably be reduced. Consequently, although reform could reduce the perception somewhat, the sense of unfairness that now surrounds the veto can be expected to continue for the foreseeable future.

As for the sense of western domination of the Council, the proposal for increasing the Council's membership would not affect the power of the West in international affairs generally, and would only marginally diminish the capabilities of the West in the Council. Rather, the main benefit appears to be that it may increase the strength of the nonpermanent members by increasing their number. This causal link between strength and number will presumably occur because more nonpermanent members will increase the linkage to the UN membership generally and will make each nonpermanent member individually more resistant to domination by the West. These results are possible, but a danger is that increased membership may interfere with the ability of the Council to operate effectively. Overall, it appears that because the present Council membership may not be reshuffled easily, the simplest thing for members to do is to call upon what appears to be a free good-increased membership. The issue, however, is the actual cost of additional membership.

Because of the uncertainty concerning the effect of increased membership and because any changes in membership will probably not be implemented until the turn of the century, the proposals to increase participation in the Council as currently constituted are especially valuable. They are valuable because they do not run the risk of undermining the Council's ability to operate owing to an unwieldy size. They are needed because the Council is being challenged now and the legitimacy of its collective authority should be strengthened. Finally, such reform would aid our understanding of precisely what changes in membership are necessary to deal with the perception of dominance of the Council by the West.

As with the proposal to increase membership, the proposals to open up Council proceedings so that members of the General Assembly would enjoy a greater sense of participation would not affect the power of the West in international affairs generally, and would only marginally diminish the capabilities of the West in the Council. Their benefit is that they would directly increase participation in the Council.

The difficulty with even this last avenue of proposals is that increased consultation with members of the Assembly and an increased sense of participation by the Assembly in Council proceedings will not alter the dominance of the few if there is a sense of urgency. This is a fundamental challenge because much of the Council's agenda is "urgent," or can be argued to be urgent. In such moments, consultation and caucuses will be slow and unwieldy in comparison with the speed with which draft resolutions will be offered by the permanent members. Here, in my view, is where the real root of dominance lies: Council proceedings often focus on a moment in time and all efforts converge on a single vote, which, when coupled with a sense of urgency, provides the greatest leverage to those with greater capabilities, the permanent members. It is to this aspect that I now turn. 


\section{Towards Mooting Dominance and Restoring Participation Through THE ELIMINATION OF THE REVERSE VETO}

What has been virtually overlooked over the past two years is that states have threatened to use the veto in a fundamentally different context. ${ }^{92}$ Moreover, this new use is part and parcel of the charge that the Council's authority is illegitimate, because this threat to employ the veto reduces the need to maintain consensus on a policy and thus is emblematic and supportive of dominance. This new use, which I term the "reverse veto," does not block the Security Council from authorizing or ordering an action but, rather, blocks it from terminating or otherwise altering an action it has already authorized or ordered. The recent surge in Council activity requires that we distinguish between the authority to initiate an action and the authority to modify an action already initiated. If this distinction is made, it is argued below, both internationalists and realists should agree that the reverse veto is not desirable. Most importantly, this use of the veto, unlike its other uses, can be addressed without amending the Charter.

\section{The U.S. and UK Threats to Use the Veto in the Gulf Crisis}

The reverse veto was threatened in the closing days of the gulf war. In that instance it would not have blocked the United Nations from undertaking an action; rather, it would have kept the United Nations from backing off from something it had already authorized. The Security Council in Resolution 678 had authorized "Member States co-operating with the Government of Kuwait . . . to use all necessary means to uphold and implement [the Security Council's resolutions regarding the Iraqi invasion] and to restore international peace and security in the area." ${ }^{\text {"93 }}$ As Iraq withered beneath the air attacks of the coalition, peace initiatives were actively pursued by various countries. ${ }^{94}$ In response, particularly to the Soviet peace efforts, both the United States and the United Kingdom reportedly stated that they had the power to maintain the UN sanctions and to continue the use of force authorized by the Council because any alteration of the sanctions or the authorization to use force would require a new resolution that they, as permanent members, could veto. ${ }^{95}$

Since then, other references to this use of the veto have been made. Prime Minister John Major reportedly stated on May 11, 1991, in a speech to the Congress of the Conservative Party, that the United Kingdom would veto any resolution aimed at easing the sanctions against Iraq as long as Iraqi President Saddam Hussein remained in power. ${ }^{96}$

\footnotetext{
${ }^{42}$ A brief reference to this use of the veto can be found in Richard Gardner, Practical Internationalssm: The United States and Collective Security, SAIS Rev., Summer-Fall 1992, at 35, 43.

${ }^{43}$ SC Res. 678, supra note 4, para. 2.

${ }^{41}$ See, e.g., Excerpts From the Statement By Gorbachev on Gulf War, N.Y. TIMES, Feb. 10, 1991, \$1, at 12: New Peace Plan at U.N., N.Y. Times, Feb. 15, 1991, at A6.

${ }^{45}$ Paul Lewis, U.S. and Britain Assert U.N. Power: They Say They Can Continue Sanctions and the War, N.Y. TImes, Feb. 22, 1991, at A4.

${ }^{4+6}$ The UK position was particularly troubling to some states because none of the Security Council's resolutions call for the removal of President Hussein. In his letter of May 13, 1991, to the President of the Security Council, the Iraqi Minister for Foreign Affairs used Major's statement to invoke the underlying question of the legitimacy of a Council arrangement that could allow Britain to take such an action:
} 
The critical point here is that these threatened uses turn the realists' justification for the veto completely on its head. .In the realist argument, a properly assigned veto is justified because all of the major players should be in agreement on any peace-enforcing effort. Here, however, the veto now means that any one of the major players, having jointly authorized the use of force or the imposition of sanctions, may force the authorization or imposition to continue.

To illustrate, let us assume that during the spring of 1993 the Clinton administration was successful in convincing a vast majority of Council members to support the adoption of more aggressive steps to stop "ethnic cleansing" in Bosnia, one of these steps being the lifting of the arms embargo. However, one-possibly two-of the permanent members then vetoed the effort to end the arms embargo. With such widespread division among states, the embargo, as a practical matter, would likely have fallen apart. But this division probably also would have placed a great strain on both the authority and the legitimacy of the Council. If the realists' justification for the veto was to prevent precisely such a division, the reverse veto should not be desirable in their view.

\section{Must the Council Terminate Its Actions? The Charter and Rhodesia}

The Charter is silent on the means of termination or, more generally, modification of actions taken by the Security Council. Nonetheless, interpreting the Charter so as to ensure its effectiveness leads quite clearly to the position that it is for the Council itself to end or modify its actions. The United States and the United Kingdom, in supporting this interpretation of the Charter in the context of the gulf war, cited the fact that the sanctions against Rhodesia were terminated by Security Council resolution. It is ironic that the United States and the United Kingdom should so refer to the Rhodesian sanctions because, although the handling of that incident does support this interpretation of the Charter, these two states were at best weak supporters of that conclusion at the time.

The Rhodesian situation first came before the Council in 1963, but the Council's extended consideration of it began with the Unilateral Declaration of Inde-

Does this not mean that the United Kingdom, as a permanent member of the Security Council, seems fully prepared to violate its obligations and responsibilities under the Charter and do so in a premeditated way, without any valid legal reason and in blatant contradiction to those responsibilities?

We warn against this dangerous precedent in international relations, which, if sanctioned, will destroy the entire basis on which the Charter of the United Nations rests . . . .

UN Doc. S/22591, at 2-3 (1991).

The United States maintained a similar view on removing President Hussein, although both Britain and the Clinton administration in 1993 backed off from this position. Paul Lewis, U.S. and Britain Softening Emphasis on Ousting Iraqi, N.Y. TIMES, Mar. 30, 1993, at A3:

Both President George Bush and Prime Minister John Major had said on several occasions that the sanctions must remain until President Hussein has been toppled . . . .

Their insistence . . . has become increasingly unpopular with other Arab countries because it clearly exceeds the Council's decisions... .

Neither the United States nor Britain mentioned this condition today when the Security Council reviewed the embargo.

See also Elaine Sciolino, Clinton to Scale Down Program to Oust Iraqi Leader, N.Y. Times, Apr. 11, $1993, \S 1$, at 3 . 
pendence by the Ian Smith Government in $1965 .{ }^{97}$ The Council condemned this act and called upon states not to recognize or assist the illegal regime. ${ }^{98}$ Ultimately, the Security Council, on May 29, 1968, unanimously adopted Resolution 253 establishing comprehensive and mandatory sanctions by all member states against the illegal government of Southern Rhodesia. ${ }^{99}$

The first time the Security Council considered lifting the sanctions occurred in connection with bilateral negotiations in 1971 between the Smith government and the United Kingdom, which had resulted in the Home-Smith Proposal. The United Kingdom had developed "five principles," which, if met and if agreeable to the Rhodesian people, would permit the British granting of independence to Southern Rhodesia. ${ }^{100}$ In November of that year, the United Kingdom requested a Council meeting to discuss an agreement on ending the Southern Rhodesian problem. ${ }^{101}$

The Security Council proceeded to discuss the UK proposal on February 16, 1972. A week later, the Soviet representative to the Council asserted that "certain States are openly attempting to throw aside the Security Council decisions on sanctions, to forget them themselves and to try to make others forget them."102

\footnotetext{
${ }^{47}$ Between 1963 and 1980 , the Security Council met 128 times on the Southern Rhodesian problem. Bailey, supra note 61, at 308. See generally Vera GowllaND-DEBBas, Collective Responses to ILLEGAL ACTS IN INTERNATIONAL. LAW: UNITED NATIONS ACTION IN THE QUESTION OF SOUTHERN Rhodesia (1990); Patil, supra note 59, at 170-89; Harry R. Stack, Sanctions: The Case of RHODESIA (1978).

${ }^{9 k}$ SC Res. 216, UN SCOR, 20th Sess., Res. \& Dec., at 8, UN Doc. S/INF/20/Rev.1 (1965).

${ }^{49}$ Acting under chapter VII of the Charter, the Council decided that "all States Members of the United Nations shall prevent" the import into their territories of all commodities and products originating in Southern Rhodesia, the sale or supply of any commodities or products to Southern Rhodesia, and any activity by nations that would promote the movement of such commodities. In addition, each member state was required to prevent entry into its territory of any person traveling on a Rhodesian passport and prohibit airline service to or from Southern Rhodesia. A committee on implementation was formed and the United Kingdom was asked to provide "maximum assistance." Although further efforts to strengthen these sanctions would be made and in some cases taken, the essential system of sanctions was contained in Resolution 253, UN SCOR, 23d Sess., Res. \& Dec., at 5,
} 6, UN Doc. S/INF/23/Rev.1 (1968).

In June 1969 , a draft resolution that would have widened and strengthened the sanctions failed by a vote of 8-0-7. 1969 UN Y.B. 115. During the same period, the General Assembly passed Resolution 2508 (XXIV), UN GAOR, 24th Sess., Supp. No. 30, at 67, UN Doc. A/7630 (1969), which condemned the intervention of South Africa into Rhodesia and "[r]eaffirm[ed] its conviction that the sanctions will not put an end to the illegal racist minority régime in Southern Rhodesia unless they are comprehensive, mandatory, effectively supervised, enforced, and complied with." Id., para. 13.

Two draft resolutions failed to be approved by the Security Council early in 1970 . The United Kingdom put forward a resolution that would have prevented recognition of the newly proclaimed Rhodesian Republic. The African and Asian representatives felt this was a diversionary measure and attempted to pass a resolution that would have authorized the use of force to implement Resolution 253. The African-Asian resolution failed by only 7-0-8. 1970 UN Y.B. 158. Finland then introduced a compromise resolution, which was adopted quickly as Resolution 277 . This resolution introduced very little that had not already been resolved. SC Res. 277, UN SCOR, 25th Sess., Res. \& Dec., at 5, UN Doc. S/INF/25 (1970). Resolution 288 was likewise a holding resolution, deciding "that the present sanctions against Southern Rhodesia shall remain in force." SC Res. 288, id. at 7.

${ }^{100}$ Letter from the representative of the United Kingdom of Great Britain and Northern Ireland to the President of the Security Council (Dec. 1, 1971), UN SCOR, 26th Sess., Supp. for Oct.-Dec. 1971 , at 60 .

tol In December 1971, Somalia introduced a draft resolution before the Security Council that would have rejected the British proposal. The United Kingdom exercised its veto to prevent passage of the resolution. 1971 UN Y.B. 100-01.

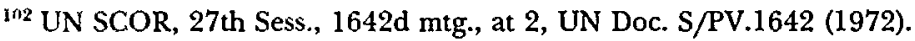


He continued, "[T] he sanctions introduced by the Security Council are not only mandatory, but fundamentally imperative" under chapter VII. "[N] single State has the right to violate them unilaterally." 103 Speaker after speaker from African and other developing states condemned the UK proposal.

Somalia, Guinea and Sudan introduced a draft resolution providing that the present sanctions would remain in effect until the aims and objectives of Resolution 253 were met, urging all states to comply, and holding domestic statutes in violation of Resolution 253, such as the Byrd Amendment in the United States, "contrary to the obligations of States." ${ }^{104}$ Somewhat plaintively, the British representative asked "the Council [to] suspend judgment on the proposals until we know the results" of the Peace Commission's investigation of Rhodesian public opinion. ${ }^{105}$ The African draft was adopted as Resolution 314 by a vote of thirteen in favor, none against, and two-the United Kingdom and the United States-abstaining. ${ }^{106}$ Shortly thereafter, the United Kingdom informed the Council that the Peace Commission had found "that the people of Rhodesia as a whole did not regard the Proposals as an acceptable basis for independence."107 "We feel," he continued, "that the best atmosphere for constructive discussion and advance will be provided if we maintain the situation as it is today, including sanctions, until we can judge whether or not an opportunity for a satisfactory settlement will occur." 108

The second instance accompanied the end of the crisis in 1979. In that year, several initiatives raised the question of which entities possessed the authority to bring the crisis to an end. Resolution 445, for example, condemned the Rhodesian elections scheduled for April 1979, which were aimed at reaching an "internal settlement," and called on the Committee on Sanctions to strengthen and widen the sanctions. ${ }^{109}$ The African states and the Soviet Union feared that the United Kingdom or the United States would send observers to the "internal settlement" elections so as to legitimate them and then use the results to justify terminating their compliance with the sanctions regime. ${ }^{110}$

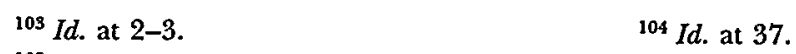

${ }^{105}$ UN SCOR, 27th Sess., 1640th mtg., at 6, UN Doc. S/PV.1640 (1972).

${ }^{106}$ SC Res. 314, UN SCOR, 27th Sess., Res. \& Dec., at 7, UN Doc. S/INF/28 (1972). In abstaining from voting on the African proposal, the United States stated that "we cannot accept those parts of the draft resolution which directly or indirectly affect laws which have been adopted and are now in force and which under our Constitution must be implemented." UN SCOR, 27th Sess., 1645th mtg., at 4, UN Doc. S/PV.1645 (1972).

${ }^{107}$ Letter from the representative of the United Kingdom of Great Britain and Northern Ireland to the President of the Security Council (May 23, 1972), UN SCOR, 27th Sess., Supp. for Apr.-June 1972, at 66 (containing text of speech given in House of Commons by Sir Alec Douglas-Home on May 23, 1972).

${ }^{108}$ Id.

${ }^{109}$ SC Res. 445 , UN SCOR, 34th Sess., Res. \& Dec., at 13, UN Doc. S/INF/35 (1979).

${ }^{110}$ The representative of Ethiopia stated that "Africa is of course fully aware that the moves currently taking place in Washington and London to send observer missions to Rhodesia are primarily intended to lend legitimacy to the process and its results, thus creating a pretext for the lifting of economic sanctions." UN SCOR, 34th Sess., 2119th mtg., at 2, UN Doc. S/PV.2119 (1979). The Soviet delegate continued along the same line; the United Kingdom and the United States were using the internal solution "as a pretext to refuse to enforce or to observe the sanctions established by the Security Council against Southern Rhodesia." Id., 2120th mtg., at 4, UN Doc. S/PV.2120. The representative of Ghana sounded the strongest warning, stating that "measures should be taken . . . against the danger of unilateral action to lift sanctions against Ian Smith." If this were to occur, it would be a "flagrant and appalling breach of Charter obligations." He asked, "What would be left of 
Anticipating what was soon to follow, the President of the Security Council's Committee on Sanctions sent a letter to the Council stating:

The Committee had learned with distress that the United Kingdom Government contemplated the non-renewal of some sanctions . . . and the lifting of the rest, "as soon as Rhodesia returns to legality with the appointment of a British Governor and his arrival in Salisbury". . . . The Committee emphasized that only the Security Council, which had instituted the sanctions in the first place, had a right to lift them. ${ }^{111}$

The next month, the bilateral political settlement known as the Lancaster House accord accentuated the question of authority. On December 12, 1979, the United Kingdom informed the Council that as a result of the Smith regime's acceptance of the resumption of full legislative and executive authority over Southern Rhodesia by a British governor,

the state of rebellion in the Territory has been brought to an end.

. . . In these circumstances, the obligations of Member States under Article 25 of the Charter in relation to [the sanctions] are, in the view of the Government of the United Kingdom, to be regarded as having been discharged. This being so, the United Kingdom is terminating the measures which were taken by it pursuant to the decisions adopted by the Council in regard to the then situation of illegality. ${ }^{112}$

The African Group in the United Nations promptly characterized the unilateral action by the United Kingdom as unacceptable and illegal. "The African Group declares that resolution 253 (1968) can be revoked only by a decision of the Security Council and that any unilateral action taken in this context is a violation of the responsibilities assumed by Member States under Article 25 . . . ."113 Despite these statements, the United States lifted its sanctions on December 16. Days later, the USSR declared that "these unilateral acts by the countries concerned represent a flagrant violation of the United Nations Charter, since only the Council can terminate the effect of decisions which it has taken."114

On December 18, 1979, the United Kingdom asked the Security Council to consider the matter of Southern Rhodesia. ${ }^{115}$ In light of the seemingly fundamental disagreement over the procedure for termination of sanctions, it is somewhat

[the United Nations'] effectiveness if the Security Council, the one organ that can make binding decisions, could be disregarded as lightly as the General Assembly, alas, so often is?" Id. at 13.

"II" Letter to the President of the Security Council from the Chairman of the Security Council Committee established in pursuance of resolution 253 (1968) concerning the question of Southern Rhodesia (Nov. 9, 1979), id., Supp. for Oct.-Dec. 1979, at 61, 62 (quoting a statement by the UK Secretary of State for Foreign and Commonwealth Affairs in Parliament on Nov. 7, 1979).

112 Letter from the representative of the United Kingdom of Great Britain and Northern Ireland to the President of the Security Council (Dec. 12, 1979), UN SCOR, 34th Sess., Supp. for Oct.-Dec. 1979 , at 119,120 .

"Ix Letter from the representative of Madagascar to the President of the Security Council (Dec. 14, 1979), id. at 131 .

114 Letter from the representative of the Union of Soviet Socialist Republics to the President of the Security Council (Dec. 21, 1979), id. at 138, 138.

${ }^{115}$ Letter from the representative of the United Kingdom of Great Britain and Northern Ireland to the President of the Security Council (Dec. 18, 1979), id. at 137. 
surprising that there was no debate at the Council's meeting of December 21, 1979, which terminated the sanctions. ${ }^{116}$

After the vote, the United Kingdom stated: "Our view remains that the obligation to impose those sanctions fell away automatically with the return to legality of the colony. But we have been very conscious that many countries have attached great importance to the adoption by the Council of a resolution on this subject."117 The United States merely expressed its pleasure that "the Council is calling upon Member States to terminate the measures taken against Southern Rhodesia under Chapter VII of the Charter because the objective of those measures has been achieved. It was in recognition of that fact that the United States made its recent announcement regarding sanctions." 118 Tanzania, however, recognizing the import of what had just occurred, stated that the Council could not "accept individual interpretations concerning [sanctions], because if such a state of affairs is tolerated then the very fabric of international intercourse and international law will be placed in serious jeopardy." 119

Thus, although not as tidy as the simple references made by the United States and the United Kingdom during the gulf war would have it, the Rhodesian case does stand for the proposition that Council actions must be terminated by subsequent Council action. If there was ambiguity in the view of the two nations at the time of the Rhodesian sanctions, that ambiguity was resolved by their statements toward the end of the gulf war. ${ }^{120}$

\section{The Political Implications of the Reverse Veto}

The reverse veto can affect the politics of the Council in two ways. First, if its net effect is to increase the dominance of the permanent members in Council deliberations that revisit an action already taken, then the reverse veto makes the initial decision all the more important. As Marquis wrote:

i do not think the prudent one

hastes to initiate

a sequence of events which he

lacks power to terminate ${ }^{121}$

In the Council at moments of urgency, not all the details of resolutions can be worked out to everyone's satisfaction. But integral to the perception of dominance is the assertion that most members of the Council do not have a say about

\footnotetext{
${ }^{116}$ Resolution 460 passed by a vote of 13-0-2 (Czechoslovakia and the USSR abstaining). The resolution decided, "having regard to the agreement reached at the Lancaster House conference, to call upon Member States to terminate the measures taken against Southern Rhodesia under Chapter VII of the Charter." SC Res. 460, UN SCOR, 34th Sess., Res. \& Dec., at 15, UN Doc. S/INF/35 (1979).

${ }^{117} I d ., 2181$ st mtg., at 2, UN Doc. S/PV.2181.

118 Id. at 8.

119 Id. at 19.

${ }^{120}$ See, e.g., Statement of Mr. Pickering, representative of the United States, UN Doc. S/PV.2977, at 301 (part II) (closed) (Feb. 23, 1991) ("it is only here in the Security Council that we could agree to lift sanctions against Iraq"); Statement of Sir David Hannay, representative of the United Kingdom, id. at 313 ("only the Security Council itself can make that judgement").

As to the views of others, see, e.g., Statement of Mr. Munteanu, representative of Romania, $i d$. at 332 ("the sanctions against Iraq can be lifted only by the Council itself").

121 Don MARQuIS, Archy and Mehitabel, poem 42, "Prudence." I wish to thank my colleague, Stefan A. Riesenfeld, for bringing this passage to my attention. He employed it in The French System of Administrative Justice: A Model for American Law? Part III, 18 BosTON U. L. REv. 715, 748 (1938).
} 
the details of resolutions. This situation requires that trust be placed in those who dominate. But if that trust is weak, those who are dominated will be suspicious about the details they cannot influence. Writing on the future of the type of U.S. leadership shown in the Council during the gulf war, three scholars cautioned: "For in order to give leadership concrete meaning, a leader must have followers, those willing to buy into a broad vision of collective goals articulated by a leader in whom both legitimacy and trust are placed."122 The reverse veto accentuates this dependency because it suggests that the initial action the followers "buy into" will not be reversible. The review process of the institution does not allow much space for trusting a leader, or suffering a mistake.

Second, the reverse veto increases the importance of the initial decision because it curtails the already limited ability of actors both within and without the Council to end a crisis by negotiation. The mere possibility of a reverse veto fundamentally alters the proceedings that follow. For example, in the gulf war, each permanent member's ability to veto any resolution aimed at stopping or altering the authorization to use force meant that the United States or Britain could insist that Iraq accept and implement unconditionally all of the Security Council's resolutions. ${ }^{123}$ For those seeking a way to end the fighting, there seemed to be very little ground for discussion and perhaps even less likelihood that any initiative would survive a veto. ${ }^{124}$ Indeed, there is a parallel to the Rhodesian situation in the Soviet peace initiative's assertion that ending the factual basis for the resolutions would cause the resolutions to lapse. (However, the UK statement regarding the Rhodesian sanctions was not as far-reaching; it declared that the obligations in the resolutions would lapse, while the Soviet initiative would have had the resolutions themselves lapse.) Specifically, under the Soviet initiative then evolving, the Iraqi troops were to withdraw from Kuwait over a twenty-one-day period and "[i]mmediately after the completion of the withdrawal of troops from Kuwait, the reasons for the adoption of other Security Council resolutions would have lapsed, and those resolutions would thus cease to be in force." 125 The United States observed in response that

[i]t is difficult for us to see how an unconditional proposal [i.e., that Iraq comply with the Council's resolutions] can be so conditioned, particularly in respect of the idea of declaring that Security Council resolutions somehow cease to exist, are null and void or without effect . . . . We must not dismantle at the stroke of a pen what the Council has built since August 2 until we have reached agreement on how to restore peace and security to the area. ${ }^{126}$

This exchange is not recounted to suggest that the United States and others were not justified in seeking full Iraqi compliance with the resolutions or in opposing any grant of a cease-fire that might have allowed Iraq to consolidate whatever

\footnotetext{
$1 \times 2$ Cooper, Higgott \& Nossal, supra note 40, at 408.

${ }^{12 *}$ Paul Lewis, U.S. and Britain Insist on Deadline: Tell Soviets Iraq Must Agree to Kuwait Pullout in Days, N.Y. TImes, Feb. 21, 1991, at A1.

I24 New Peace Plan at U.N., N.Y. Times, Feb. 15, 1991, at A6 ("The latest peace proposal calls for a halt to the allied bombing and the appointment of a Security Council commission to examine [by Feb. 25] ways of ending the fighting. . . . Diplomats said the proposal had no chance of being adopted because the United States would certainly veto it.").

${ }^{125}$ Statement of Mr. Vorontsov, representative of the Soviet Union, UN Doc. S/PV.2977, supra note 120 , at 296.

12t Statement of Mr. Pickering, id. at 303-06.
} 
defenses it retained. ${ }^{127}$ Rather, it illustrates how the presence of resolutions and their relative irreversibility due to the veto altered the argumentation employed and the political options possible.

A similar effect on settlement possibilities can be seen in the early stages of the Rhodesian situation. Although Ian Smith might have been able to reach some agreement with the United Kingdom and possibly the United States, the discussions before the Council should have indicated to him that such bilateral settlements would not necessarily result in the lifting of UN sanctions. Consequently, one can see the logic of the British position regarding the Rhodesian sanctions. To pursue a settlement with Rhodesia, the United Kingdom needed to be able to free itself of its obligations under the resolutions, and, even better, to lay the foundation for the argument that the obligations generally had ceased to have force.

These examples point to the importance of distinguishing between the authority to initiate an act and the authority to terminate or modify an action already initiated, and to the recognition that the difference between the two justifies different voting formulas. In a manner analogous to the way the standard of review used by an appellate court determines the distribution of power between the appellate and trial court levels, so does the voting procedure to terminate or modify an action influence the content, and even likelihood, of the actions taken.

\section{Dealing with the Reverse Veto}

Although dealing with the veto, and the double standard that may be perpetuated by it, would require amending the Charter, dealing with the threat of a veto on action already taken or authorized need not require such an amendment. The approach would be to incorporate in any resolution taking a decision a modified voting procedure for future use in terminating the action taken. The idea appears both possible and desirable.

The legality of a modified voting clause. When I mentioned the idea of a modified voting clause to a lawyer serving with the mission of one ' of the permanent members of the United Nations, his reaction was quick and dismissive. He stated that such a bootstrap approach was not possible; a permanent member may not agree to waive its veto.

I can discern no support for the argument as a matter of treaty law. First, if it so desired, the Council could simply designate a termination date or terminating event for any authorization. This approach waives not only the veto, but the vote altogether. In this regard, it is interesting to revisit the positions of the United States and the United Kingdom on the Rhodesian sanctions. In essence, they claimed that the sanctions terminated automatically when the rationale for imposing them ceased to exist. An example of a time-dependent termination, a "sunset provision," is the Council's practice of authorizing peacekeeping forces for only a certain period of time. ${ }^{128}$

\footnotetext{
${ }^{127}$ The discussions that took place in the Security Council at the time of the Soviet initiative make clear that a veto would not have been necessary, since many members demanded that Iraq comply with the resolutions and stated that it was for the Council to authorize any change in the actions taken against it.

${ }^{128}$ See, e.g., SC Res. 426, UN SCOR, 33d Sess., Res. \& Dec., at 5, UN Doc. S/INF/34 (1978) (establishing the United Nations Interim Force in Lebanon (UNIFIL) for an initial period of six months). UNIFIL's mandate has been extended continuously every six months since she adoption of
} 
Second and more importantly, the Security Council on at least one occasion has already essentially altered its voting procedures via a resolution. In Resolution 687, the Council created a Compensation Commission to address claims against Iraq arising out of the gulf war and requested that the Secretary-General make recommendations for the Commission's operation. ${ }^{129}$ On May 2, 1991, the Secretary-General suggested that the Commission "function under the authority of the Security Council and be a subsidiary organ thereof." He recommended that the "principal organ" and policy-making body of the Commission be a "15-member Governing Council composed of the representatives of the current members of the Security Council at any given time." 130 As for the decision-making process of this Governing Council, he recommended that,

[e]xcept with regard to the method of ensuring that payments are made to the [Compensation] Fund, which should be decided upon by consensus, the decisions of the Governing Council should be taken by a majority of at least nine of its members. No veto will apply in the Governing Council. If consensus is not achieved on any matter for which it is required, the question will be referred to the Security Council on the request of any member of the Governing Council. ${ }^{131}$

The Security Council adopted the recommendations of the Secretary-General in Resolution $692 .^{132}$ The overall effect was to delegate a decision-otherwise subject to the veto--to a subsidiary organ (with the same membership as the Council) where the veto does not apply. By analogy, could not the Council delegate all further decisions regarding a sanctions regime to a similar subsidiary body operating without a veto? And if the Council could do so, then why can it not simply alter its own voting procedures for future decisions on a particular action it has taken? ? $^{133}$

The drafting of modified voting clauses. A modified voting clause requires careful drafting both to avoid a double veto situation and to meet the demands of the situation presented. There should be no need to discuss whether the second resolution modifies the first or whether it creates new obligations, a categorization issue, to which the veto might apply-i.e., a double veto situation. For example, assume that a resolution authorizing sanctions states, "any decisions terminat-

Resolution 426. See, e.g., SC Res. 701 (July 31, 1991) (extending mandate of UNIFIL for a further interim period of six months until Jan. 31, 1992).

See also UN Doc. S/5575 (1964) (recommending the stationing of a UN peacekeeping force in Cyprus for a period of three months), most recently extended by SC Res. 759 (June 12, 1992); SC Res. 693 (May 20, 1991) (establishing the UN Observer Mission in El Salvador for an initial period of twelve months).

129 SC Res. 687 (Apr. 3, 1991), reprinted in 30 ILM 852 (1991).

${ }^{150}$ Report of the Secretary-General pursuant to paragraph 19 of Security Council resolution 687 (1991), UN Doc. S/22559, paras. 4, 5 (1991), reprinted in 30 ILM at 1706.

${ }^{131}$ Id., para. 10 (emphasis added).

152 SC Res. 692 (May 20, 1991), reprinted in 30 ILM at 864.

195 Nor would it seem that a permanent member could reassert its veto because of changed circumstances. Article 62 of the Vienna Convention on the Law of Treaties, opened for signature May 23, 1969,1155 UNTS 331, limits the invocation of changed circumstances to situations where the effect of a "fundamental" change "is radically to transform the extent of obligations still to be performed." Putting aside the issue of whether the treaty in question is the Charter or a resolution, it would seem rare indeed that the requirements of Article 62 could be met. See Georg Schwarzenberger, Clausula Rebus Sic Stantibus, [Installment] 7 ENCYCLOPEdia OF Public InTERNATIONAL Law 22 (1984). 
ing or modifying the measures taken in this resolution shall be made by an affirmative vote of [for example] twelve members." If a proposal were made to broaden the economic sanctions ordered in the original resolution to include certain banking transactions, a voting "border question" would arise. Is the proposal a modification of the existing regime and therefore subject to the modified voting procedure, or is it a new sanction and therefore subject to the voting procedure set forth in the Charter? The border question posed in the hypothetical would seem to be decided by the voting procedures set forth in the Charter, and thus the veto would probably apply to it.

Consequently, the preferred drafting approach would be categorical; for example, "any decision to terminate any or all of the measures taken in [for example] paragraphs 1 through 9 of this resolution shall be made by an affirmative vote of [for example] twelve members." The limitation of the language to an effort to terminate enumerated measures leaves little room for ambiguity and thus steers clear of the border question.

Of course, there could be many variations on the modified voting procedure. The exemplary language above, "an affirmative vote of twelve members," would mean that any effort to terminate a sanction could be blocked by the vote of four states, as opposed to the current possibility that one of the permanent members could block termination. "An affirmative vote of thirteen members" would mean that any effort to terminate a measure could be blocked by the vote of three states. And so on. Note, however, that if the language were "an affirmative vote of all the members of the Council," this would not be equivalent to the current situation because only the permanent members can now exercise the reverse veto, while the quoted language in effect extends the reverse veto to all the members of the Council. ${ }^{134}$

In general, I think the required number of affirmative votes to terminate a resolution should be high so as to prevent political maneuvering by the state at which the resolution is directed. Just as the reverse veto at present means that the target state may have little chance to terminate the authorization or order in a resolution if a permanent member is strongly opposed, so a modified voting procedure-eliminating the reverse veto-might mistakenly encourage the target state to attempt to split the Council. Thus, the required affirmative votes should probably be higher than the nine required as an initial matter, but not so high, say fourteen, as virtually to perpetuate the present situation regarcling the reverse veto. ${ }^{135}$

The choice among drafting variations extends not only to the number of votes required, but also to other conditions regarding both the voting and the implementation of the terminating resolution once adopted. For example, if the question involves termination of an authorization to use force, the resolution on modified voting procedure might (1) provide for a particularly high number of states to terminate, for example thirteen; (2) limit efforts at termination to once every six months; (3) provide that if the authorization is terminated, there then be reason-

\footnotetext{
${ }^{134}$ Conversely, if the permanent members did not have a veto at all, the blocking of any effort to terminate a measure already taken, were it not modified in the manner described above, would require negative votes by six states.

${ }^{135}$ In the event, it may not always be desirable for the required number of votes to be higher than nine. Only six votes could be mustered in June 1993 to lift the arms embargo on Bosnia. Richard Bernstein, Security Council Stops Move to Arm Bosnians, N.Y. Trmes, June 30, 1993, at A4. The higher number of votes required represents a balance between not encouraging strategic behavior by the target state and trusting in the ability of the-Council to modify previous actions when appropriate.
} 
able time for orderly withdrawal; and (4) indicate that any such termination will be without prejudice to the right of the participating states to protect their forces as necessary. Clearly, the drafting choices likely will, and should, be greatly influenced by the particular situation.

Policy and political considerations regarding modified voting clauses. The politics of modified voting clauses raises numerous questions: are such clauses desirable from the perspective of the international community, the United Nations, the nonpermanent members and the permanent members, and, depending on the answers to these questions, how likely is it that such clauses could be adopted?

The nonpermanent members would probably find the modified voting clause desirable in that it would lessen the significance of the initial decision, which because of a sense of urgency is dominated by the permanent members. It is the possibility of the reverse veto that gives an assurance of the continuance of domination. A modified voting clause would empower the nonpermanent members by allowing them to revisit the decision at a later date.

The modified voting clause is not likely to appeal to the permanent members, at least at first glance. On the one hand, if perceptions of illegitimacy are of no particular concern, the increased possibility of revisiting a resolution would seem to be a needless distraction. Moreover, in view of the intensity with which these states defend the prerogative of the veto, the possibility of any modified voting procedure, even if limited, might seem threatening to that prerogative. On the other hand, the permanent members should find such a clause desirable because it would protect them from the abusive veto of any of the other permanent members.

More importantly, the modified voting clause should be attractive to all the members of the Council because it supports the objectives of the Organization. The clause would be desirable from the perspective of collective authority because it would increase the perceived legitimacy of decision making generally by encouraging the maintenance of consensus. It would be desirable in terms of the objectives of sanctions in that it would enable the state targeted by the sanctions to act with a view to ending them. For if the target state and its citizenry conclude that, no matter what they do, the sanctions will remain in place because of the wishes of one or two permanent members, they may simply stiffen their resistance and reject further efforts to satisfy what they see as an unreasonable and unresponsive Council. ${ }^{136}$ From the perspective of the design of the United Nations, the clause would be desirable in that the promotion of an ongoing process in the Security Council would tend to lead the General Assembly back to involvement in, rather than opposition to, the Security Council.

Finally, adoption of modified voting clauses is politically feasible even if the permanent members are equivocal as to their value. The votes of the nonpermanent members are necessary for the passage of any Council resolution and, while those members may not be able to offer alternative plans of action in the short term, they may have sufficient power to demand the inclusion of a modified voting procedure for application to future reconsideration of the decision.

\footnotetext{
${ }^{136}$ A related problem is that it is not always clear what is required to end sanctions. "If the Council is so outraged that it imposes coercive sanctions against a State or regime, as in the case of Southern Rhodesia from 1966 to 1980 , it might be useful for it to indicate what the offending State or regime must do to be relieved of the sanctions." Bailey, supra note 61 , at 332 . The participatory governance that would accompany the maintenance of consensus on sanctions and the like would result in the elaboration of what is sought from the offending state.
} 
Perhaps the ability to debate, the opportunity to participate, can resolve the concerns about illegitimacy. Thus, reform should encourage the maintenance of consensus. Nevertheless, we must recognize that the opportunity to participate and to seek consensus may only make a lack of consensus more apparent, and that dealing with the reverse veto does not address directly the double standard in governance made possible by the veto power. Rather, dealing with the reverse veto serves to place concerns about legitimacy on the table, leaving it to the member states to find a consensus that addresses those concerns.

\section{CONCLUSION}

We will all long consider the implications of the end of the Cold War for the international legal system. The Cold War divided the international community and gave rise to communities among the states on each side of the divide. Even as the ending of that bipolar world brought the international community back together, it loosened the "communities of division" and allowed countries to rediscover their own selves, or lack of selves, free of either pole.

The renewed sense of global community means, at least for now, that it is possible in more areas to judge whether the conduct of a state is acceptable. There are trends both toward the tolerance of difference-as states, and parts of states, explore and debate what makes them unique - and toward judgment of the conduct of oppressive states posing foreseeable risks to international peace and security. In the face of both unaccustomed community and diversity, the world must learn to judge and tolerate, and to know whether what is called for is judgment or tolerance. In some instances it will be the Security Council that serves as judge, making, applying and enforcing the law. Therefore, it is critical to determine which parts of the international community accept, and which parts question, the legitimacy of the Security Council's authority regarding threats to international peace and security, and why they do so.

To be effective, international governance must be concentrated in some body other than the whole. The question is how to design this body so that the governed as a whole, both in fact and in perception, are served rather than oppressed. Considering the very different positions of the members of the international community and their citizenries, this article concludes that the problem of legitimacy will be an ongoing one for any effort at international governance, and that effective governance, among other things, therefore requires a process involving ongoing participation, in most cases through representatives. Indeed, the differences may be so great that we must recognize that the search for consensus regarding principled substantive bases for intervention will be difficult and, even if "successful" to some, certainly not adequate to resolve the much harder problem of applying such general principles to any particular case. Similarly, challenges to power framed in terms of the illegitimacy of that power cannot be dealt with merely on the level of general principles. Rather, the means of confronting the challenges to legitimacy must be institutionalized. This conclusion places a heavy emphasis on process, not because I believe justice is merely procedural, but because I believe our diverse global community is more likely to find its vision of substantive justice through a process involving debate. ${ }^{137}$ To the degree that the organization and its members can learn from the resulting debates, the challenges expressed in terms of legitimacy may be met.

${ }^{137}$ See HAAS, supra note 19, at 190-94. 